\title{
Dietary adaptation in Neandertal, Denisovan and Sapiens revealed by gene copy number variation
}

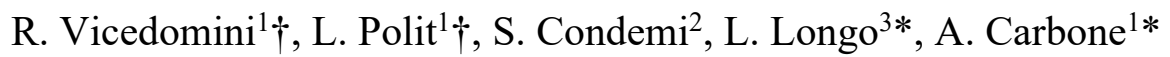 \\ ${ }^{1}$ Sorbonne Université, CNRS, IBPS, UMR7238, Laboratoire de Biologie Computationnelle et \\ Quantitative (LCQB); Paris, France. \\ ${ }^{2}$ Aix-Marseille Univ, CNRS, EFS, UMR7268, Laboratoire Anthropologie, Droit, Ethique et Santé \\ (ADES); Marseille, France. \\ ${ }^{3}$ Dipartimento di Scienze Ambientali, Informatica e Statistica (DAIS) - University Ca' Foscari; \\ Venice, Italy. \\ * Corresponding authors: alessandra.carbone@sorbonne-universite.fr, Laura.Longo@unive.it \\ $\dagger$ These authors contributed equally to this work.
}

\begin{abstract}
Dietary adaptation is the acquisition of an efficient system to digest food available in an ecosystem. To find the genetic basis for human dietary adaptation, we searched 16 genomes from Neandertal, Denisovan and Early Sapiens for food digestion genes that tend to have more or fewer copies than the modern human reference genome. Here, we identify 11 genes, including three gene clusters, with discernible copy number variation trends at the population level. The genomic variation shows how metabolic pathways for lipid, brown fat, protein or carbohydrate metabolism adapt to metabolize food from animal or plant sources. Interpreting the copy number profiles in relation to fossil evidence shows that Homo sapiens had an evolutionary advantage compared to Neandertal and Denisovan in adapting to cold and temperate ecosystems.
\end{abstract}


After the great dispersion of Homo sapiens $(H s)$ from Africa into Eurasia about 60,000 years ago (1), the other Eurasian archaic humans (EAHs), notably the Neandertals ( $\mathrm{Hn}$ ) and the Denisovans (Den) who populated this geographical region, disappeared. Reasons for the success of $H s$ are debated among specialists (see Supplementary Online Material), with food intake being one factor to be considered. Early humans ate raw fruits and leaves, then scavenged animal resources, before learning how to actively hunt. The intake of fats and meat increased, until now understood as highranking food (2). In the Late Pleistocene, foraging and mechanical transformation of carbohydrates through grinding starchy roots and grass seeds contributed to energy demand by providing vital macronutrients (3-5).

According to the pioneering study of the AMY1 gene coding for salivary amylase $(6,7)$, high starch diets became staple during the Neolithic, when people became major consumers of cereals and other starch-rich plants (roots and tubers). The diet and ecological niche of archaic humans were indicators of low versus high trophic level carnivores (8-11). The inclusion of plants in the diet of $H s$ was demonstrated to be a rich source of starch as well as proteins and fatty acids (FA) (12-16).

In this study, we consider differences in diet between the hypercarnivore EAHs and the omnivore $H s$ by studying the copy number variation $(\mathrm{CNV})$ of genes involved in digestion and metabolism. The aim was to use publicly available complete genomes of archaic humans to identify genomic changes underlying the diverse and evolving ability of humans to efficiently digest and metabolize energetic nutrients. Our CNV data show that humans living in temperate and cold latitudes had differentiated access to food sources. While both $H n$ and Den maintained strict carnivory, $H s$ has increased intake of dietary carbohydrates since its oldest occurrence in Eurasia, thus accessing this caloric food long before crop domestication emerged $(15,17)$. This novel information can be interpreted in light of the archaeological and anthropological records of human populations living across the Eurasian Steppe during the Late Pleistocene.

Genomic CNV has been studied for more than 30 years (18). Initially, it was thought that CNV was rare with a limited impact on the total extent of human genetic variation (19). With recent genomic technologies, thousands of heritable copy number variants (CNVs) within modern populations have been documented, generating considerable interest over the functional significance of gene duplication. CNV has been demonstrated to influence levels of gene transcription $(18,20-22)$ conferring an adaptive advantage, and some CNVs have been associated with differential susceptibility to complex diseases $(23,24)$. The landscape of past and present $\mathrm{CNV}$ in genomes could be of functional significance related to specific phenotypes within and across populations. Only a few genomes of human archaic populations will ever be available, but our CNV analysis shows that genes that maintain their copy number across individuals of a same population while changing copy number across populations can be indicators of adaptation to different environments.

\section{Results}

More than 70 ancient nuclear genomes are available to date, but we could only estimate gene CNV for 16 of them due to insufficient sequencing coverage, the elimination of repeated regions, and contamination of most sequenced genomes. Still, this is the largest pool of ancient nuclear genomes analyzed in this way (Figure 1 and Table S1). In this pool are key genomes from 
individuals at sites spanning temperate and cold latitudes of Eurasia (Table S2) including EAHs from the Altai Mountain - Den D3 (25), Den D11 (26), Altai Neandertal D5 (27) and Chagyrskaya 8 (28) - and the earliest $H s$ from Ust'Ishim (North Siberia) (29). To this Central Asian core sample, we added $H n$ genomes following their east-west distribution, namely Mezmaiskaya 1 (30), Mezmaiskaya 2 (31), Vindija 33.19 (also referred to as Vindija 87; 30), Goyet Q56.1, Spy 94a, and Les Cottés Z4-1514 (31). In addition to Ust'Ishim, modern human genomes belonging to Peştera Muierii 1 (32), Mal'ta (33), to the hunter-gatherers from Motala 12 and Loschbour, and to the earliest northern farmer from Stuttgart $(34,35)$ were analyzed.

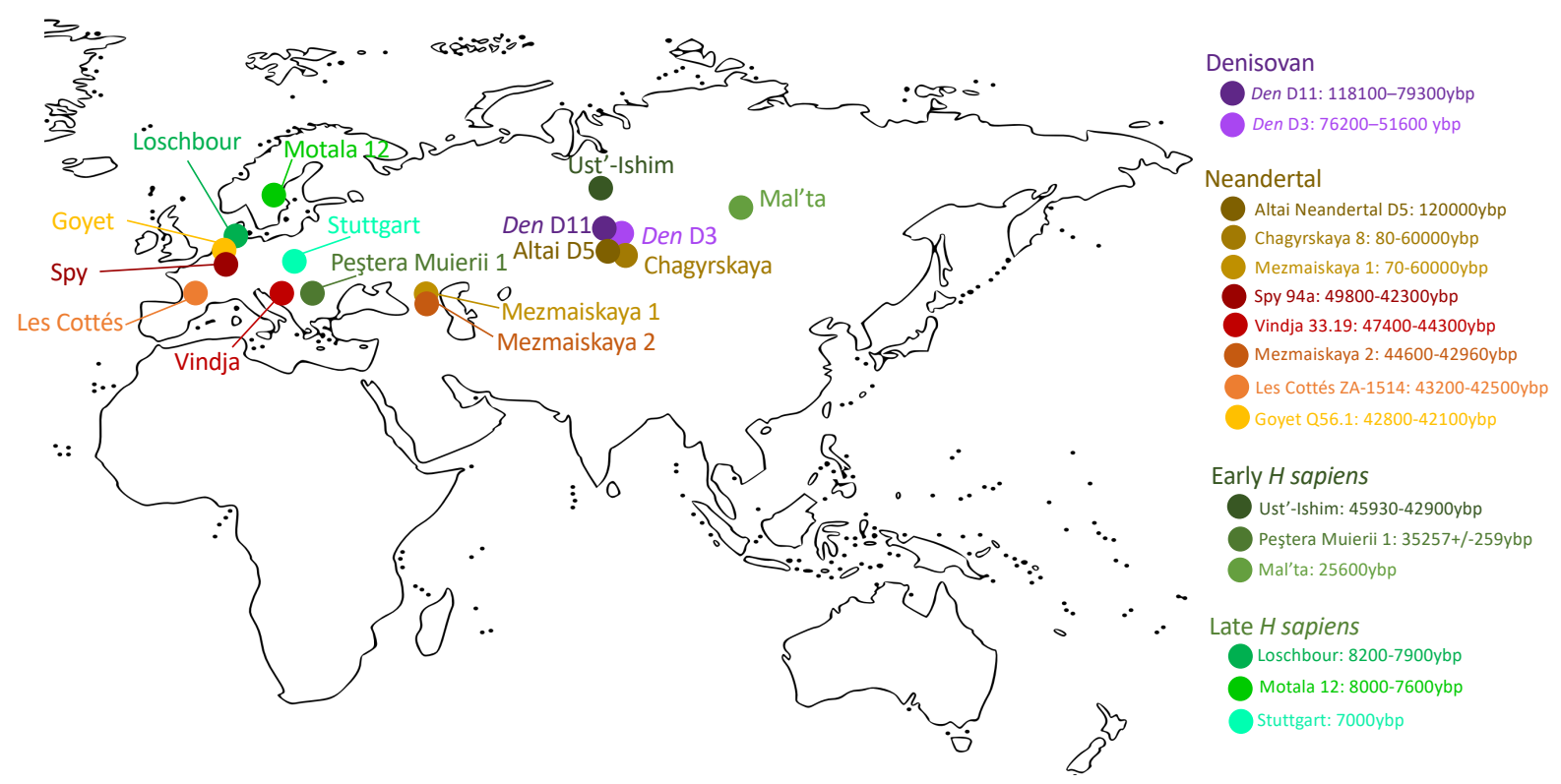

Figure 1. Geographical location of ancient genomes used for gene CNV analysis. Genomes are from individuals of early and late $H s$ (greens), $H n$ (browns, reds) and Den (purples) populations. Darker shades correspond to older time periods. Dates are calibrated.

Definition of population-dependent CNVs. To be certain of capturing the genetic changes in a population rather than specifying the genetic background of any individual, we considered genes with a differential copy number in a population. First, the actual gene copy numbers were determined. Then, the differential copy number of a gene was defined for each individual as being positive if the genome had more haploid copies than the modern reference genome (GRCh37/hg19) and negative if it had fewer copies. Next, we identified those genes with a positive or negative CNV in more than the half of the individuals of a population (see Methods). Practically, this translates as 5 or more of the $8 H n$ individuals and 4 or more of the $6 H s$ individuals. As there were only 2 Den genomes, genes were only selected if their differential CNV was the same in both genomes yet different from the reference genome. Genes not showing a population-dependent $\mathrm{CNV}$ were not selected even though they might have been duplicated in one or more genomes within a population.

We used an unsupervised approach to analyze the full datasets of genes for the 16 genomes (Figure 1) to identify a subgroup based on four criteria: the haploid copy number, the differential copy number with respect to the modern human reference genome, principal expression in organs of the 
digestive apparatus, and a Gene Ontology classification (36) related to digestion. Eleven genes involved in four overarching metabolic functions were thus identified (Figure 2A, Tables S2-S3).

The panel of 11 genes are principally expressed in digestive organs, most in a specific organ (Figure 2B). ACOT1, MST1 and NPY4R have a much wider expression. The CNV observed may therefore be an adaption to processes other than digestive activity. We excluded from our analysis any food metabolism genes $(37,38)$ which are not principally expressed in the digestive apparatus (39), even if they presented a differential CNV in a population. For instance, although BOLA2 is present at a high copy number in different Hs genomes, we excluded it because its biological function is uncertain (there is no Biological Process GO slim classification for it) and it is principally expressed in blood, even though it is possibly involved in iron regulation (20) and affected by digestion. The stringency of the expression criterion used here may mean that the current panel of genes is an underestimate of those potentially responsible for CNV-driven food adaption.

A.

\begin{tabular}{|c|c|c|}
\hline Genes & Function & $\begin{array}{l}\text { Food } \\
\text { origin }\end{array}$ \\
\hline $\begin{array}{l}\text { AMY1A/B/C, } \\
\text { SULT1A3/4 }\end{array}$ & $\begin{array}{l}\text { Dietary carbohydrates } \\
\text { digestion/ metabolism }\end{array}$ & Plant \\
\hline $\begin{array}{c}\text { ACOT1, CLPS, CLPSL1, } \\
\text { LPA, CYP2D6 }\end{array}$ & Lipid metabolism/Catabolism & Animal \\
\hline MST1, PDPR & $\begin{array}{l}\text { Liver lipid and brown fat } \\
\text { metabolism/Cold stress } \\
\text { metabolism }\end{array}$ & Animal \\
\hline$P G A 3 / 4 / 5$ & Protein metabolism & Animal \\
\hline NPY4R & Digestion/Satiety stimulation & General \\
\hline
\end{tabular}

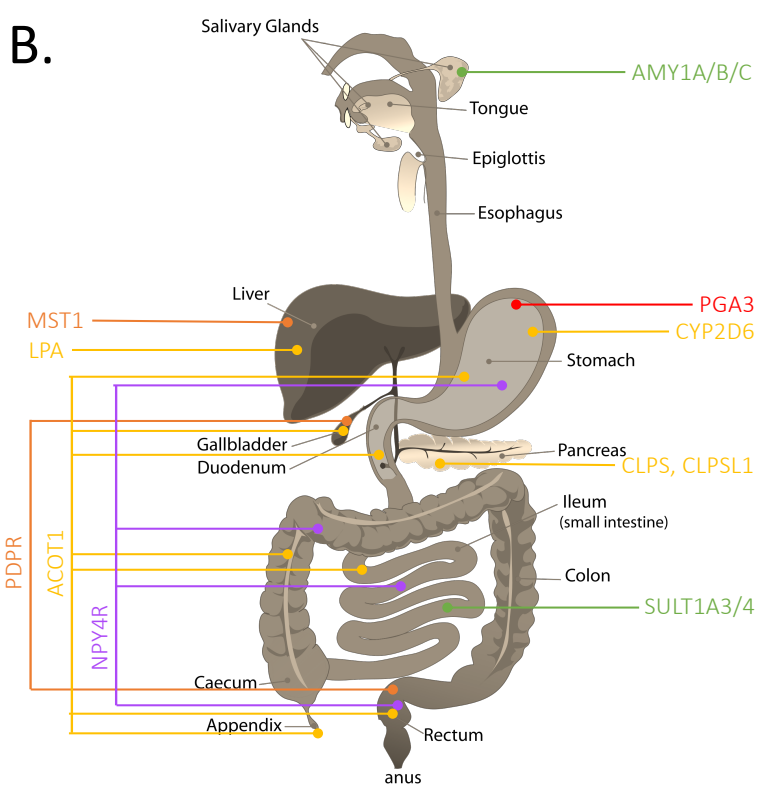

Figure 2: List of 11 genes involved in food digestion and metabolism that are characterized by a differential CNV in at least one human population compared to the reference modern genome. A. The 11 genes are grouped according to their role in digesting plant or animal foods, and their broad metabolic function. See also Table S3. B. Organs of the digestive apparatus where the 11 genes are principally expressed. See also Table S4. [The original drawing of the digestive apparatus was released into the public domain by the author LadyofHats and modified with the gene expression information.]

For the 11 genes selected with a differential CNV in a population, we checked whether there was a $C N V$ trend in another population, that is in 4 or more of the $8 \mathrm{Hn}$ individuals and 3 or more of the $6 H s$ individuals (see Methods). The AMY1A/B/C gene cluster (Table 1A; Table S5), for example, was selected by a negative differential CNV with 6 out of $8 \mathrm{Hn}$ individuals having fewer gene copies than modern humans (Table 1A). The $H s$ population does not satisfy the strict selection criterion for this cluster, but it does show a positive CNV trend, because 3 of the 6 genomes have more AMY1A/B/C gene copies than the modern genome (Table 1A). Determining the differential $\mathrm{CNV}$ trend of a gene in a population revealed several aspects. The same gene may show different trends between ancient populations. E.g. AMY1A/B/C and SULT13/4 have fewer gene copies in $H n$ and Den, but more in $H s$. Trends may be positive and negative in a single population, e.g. in $H n$, the differential CNV of ACOT1 is negative, while that of CLPS, CLPSL1 
is positive. The same trend was shared by populations. For example, positive differential CNV was found for CYP2D6 in both Hn and Den, for LPA, MST1, PDPR, and NPY4R in both Hn and $H s$, and for PGA3/4/5 in all three populations. The differential CNV captured chronological trends within populations, as shown for the MST1 and PDPR genes in $H s$, where duplication appears in Mesolithic individuals.

Among the 11 genes, we found the well-studied AMY1A/B/C gene cluster $(6,7,15-17)$, and the negative CNV trend seen in $H n$ and Den populations (Table 1) confirms the key role of the cluster in $H s$ adaptation to a different mode of food digestion and metabolism. The other ten genes have not been highlighted before as playing a role in human adaptation and are a novel panel to be investigated. They span a large spectrum of metabolic functions. The most striking feature is that for each overarching metabolic process represented, either all the genes involved in that process present a positive differential CNV for a population or a negative one (see Table 1A, rightmost columns). This is a strong indication that an adaptive force underlies the duplication of these genes in archaic populations.
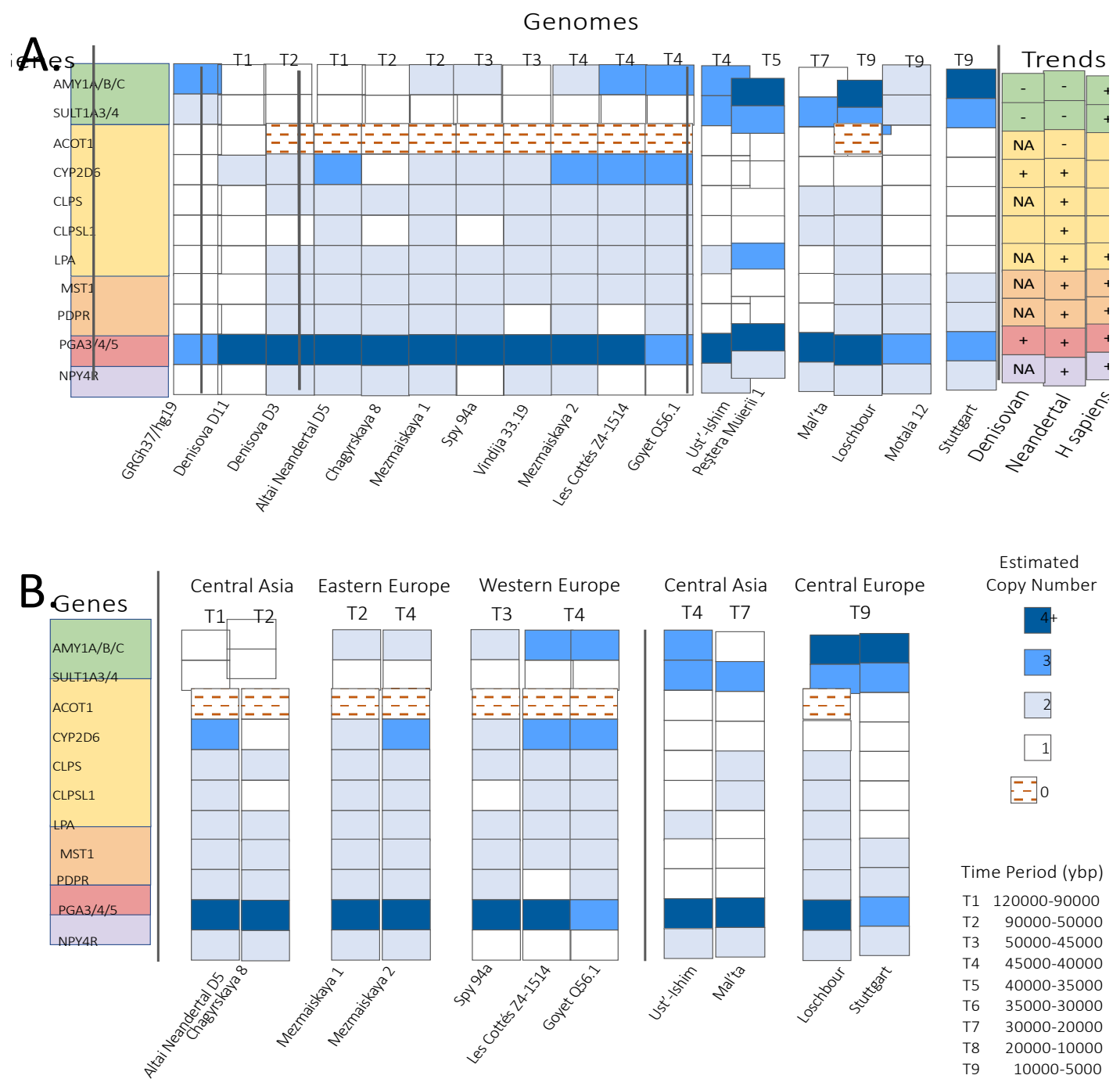
Table 1. Estimated haploid copy number for genes related to digestion in ancient genomes and differential CNV in human populations. A. Copy number of 11 genes (rows) in 16 ancient genomes and the modern human reference (columns). Individuals are grouped according to their population, from left to right, the GRCh37/hg19 reference, Den, Hn and Hs. Within a population, the order reflects the geographical origin and time period. The estimated copy numbers computed for each gene/genome (see Methods) are rounded to the closest integer (see Table S5 for specific values). The order and the color shading for gene names correspond to those used in Figure $2 \mathrm{~A}$. On the right, the differential $\mathrm{CNV}$ trends of each human population are scored for each gene as positive $(+)$, negative $(-)$, not determined (NA) or no differential trend (no symbol). B. CNV profiles of genomes in A grouped by geographical area.

Duplication of two gene clusters adapted to carbohydrate digestion. The $\mathrm{AMY} 1 \mathrm{~A} / \mathrm{B} / \mathrm{C}$ gene cluster is highly duplicated in modern humans and it is expressed in salivary glands (Figure 2B). Amylases efficiently break down starch into maltose in the oral cavity $(13,15)$. AMY1A/B/C copies range from 1 to 6 and correlate well with the degree of adherence to a primarily starchbased diet, suggesting they are adaptive. AMY1A/B/C duplication has been estimated to have emerged after the divergence between human-specific lineages and archaic hominins either approximately 550-590k ybp (7) or around 400-275k ybp $(15-17,40)$, a reconstruction that agrees with recent analyses of genomes from Cameroon (41). Across the 16 ancient genomes studied here, our data confirm that AMY1A/B/C is highly duplicated in Hs but not in $H n$ and Den (Table 1A). More precisely, the trend in $H s$ since Ust'Ishim dated at $45 \mathrm{k}$ ybp, including present-day humans, is of copy numbers greater than 3. This particularly high copy number is additional evidence that AMY1A/B/C was duplicated after the ancestral lineages split. Interestingly, the late Palaeolithic hunter-gatherer from Motala 12 (Sweden) has two copies of the cluster, although Mal'ta, the easternmost Upper Palaeolithic modern human who lived 24k ybp in severe climatic conditions in Central Asia, has only one copy of AMY1A/B/C. On the other hand, two late Hn in our sample, Les Cottés ZA-1514 and Goyet Q56.1, each have 3 copies of AMY1A/B/C.

The two human genes SULT1A3 and SULT1A4, collectively called SULT1A3/4, encode identical protein products (42). Previous genomic studies revealed the duplication of these genes during the evolutionary process $(43,44)$. From our analysis, all the EAHs have only one copy of SULT1A3/4 whereas all the $H s$, from the oldest to present-day humans, have 2 or 3 copies of this gene cluster. SULT1A3/4 is a sulfotransferase enzyme catalyzing the sulfate conjugation of many hormones, neurotransmitters, drugs, and xenobiotic compounds, and so its function depends on its tissue location (45). Highly expressed in the gastrointestinal tract of humans and closely-related primates, SULT1A3/4 indirectly influences carbohydrate metabolism (46) through dopamine sulfonation, a reaction involved in the regulation and biotransformation of catecholamines (47). The gene cluster may therefore detoxify potentially lethal dietary monoamines in the intestine and eliminate toxic compounds from the body (48). A diet that includes a large intake of starch, nuts and seeds, is rich in flavonoids, which boost the levels of serotonin and dopamine, two key neurotransmitters regulating many physiological processes under hormonal control.

Gene copy number for adaptation to fatty food of animal origin. CYP2D6, CLPS, CLPSL1, LPA and ACOT 1 all encode enzymes involved in lipid hydrolysis and oxidation of long-chain FA (i.e., arachidonic acid metabolism). More FA are consumed in diets incorporating more animal proteins and are critical for brain development and metabolism and for inflammatory responses (49). The enrichment of genes involved in lipid catabolism can be observed in EAHs and partially 
shaped northern European human populations, even contemporary ones, among whom a higher rate of $\mathrm{Hn}$ introgression is recognized (50).

ACOT genes are involved in lipid metabolism as they encode acyl-CoA thioesterase that regulates the cellular balance between free FA and acyl-CoA, feeding into key pathways for energy expenditure and neuronal function (51). In contrast with $H s$, none of the $H n$ individuals has the ACOT1 gene whereas copies of all other type I ACOT genes (52), whether peroxisomal or mitochondrial, are present in Den D11, Hn, and most $H s$. ACOT2 is $98.6 \%$ identical (53) to ACOT1 and is present as one copy in all $H s$, Den and $H n$ individuals. The ACOT2 protein is targeted to mitochondria (see Methods) and shares the same function as ACOT1. It has been demonstrated that ACOT1 regulates fasting hepatic FA metabolism by balancing oxidative flux and capacity (54). Hence the absence of ACOT1 could have been lethal for EAHs in periods when FA intake was scarce, such as during the colder stages of marine isotope stage (MIS) 3 (chiefly Heinrich Event 4) when a strong reduction in herds of large herbivores deprived EAHs of their basic food $(55,56)$. Conversely, $H s$ would have had broader access to different kinds of food. An exception is the individual from Loschbour who lacked this gene.

The CYP2D6 gene encodes a cytochrome P450 involved in arachidonic acid metabolism. Arachidonic acid is one of the omega-6 poly-unsaturated FA converted into long-chain polyunsaturated acids (LC-PUFAs), necessary for high-soliciting tissues like brain, heart, blood, liver and muscles (57-59). Hn and Den both show positive CNV trends with 2 or even 3 copies of CYP2D6 while $H s$, including modern hg19, show no duplication (Table 1A).

CLPS, CLPSL1 and LPA genes are involved in lipid digestion and lipid transport (60). Colipases (CLPS and its paralog CLPSL1, Colipase Like 1) are cofactors needed by pancreatic lipase for efficient dietary lipid hydrolysis as they allow the lipase to anchor itself to the lipid-water interface and avoid being washed off by bile salts (61). Lipases (LPA) are mainly expressed in the liver and perform essential roles in digestion, transport and processing of dietary lipids. There is huge interindividual variation in LPA levels and a high heritability of the traits, and while the physiological function of LPA is not fully elucidated, it is acknowledged to be linked to the risk of cardiovascular disease (62). Hn displays a positive CNV trend for CLPS and CLPSL1 but there is no trend in the $H s$ population (Table 1A). All $H n$ individuals and the early $H s$ Ust'Ishim and Peştera Muierii 1 have multiple copies of LPA. The hybrid Den D11 does not show duplication of any of the three genes, but has the same pattern as the much later $H s$ from Motala 12 and Stuttgart.

Adaptation to cold stress metabolism related to eating food of animal origin. Cold conditions are expected to be better tolerated by human populations that react better to cold stress. We found that both $H n$ and $H s$ populations show a positive CNV trend for two genes involved in this metabolic process - MST1 and PDPR - compared to the modern human genome. We noted that the trend was due to the positive differential CNV of both genes in the Holocene $H s$ individuals, while the three early $H s$, Ust'Ishim, Peştera Muierii 1 and Mal'ta, have single copies of each gene.

MST1 (Macrophage stimulating 1) gene is known to be important in liver lipid metabolism, limiting liver damage that might be induced by a high-fat diet or during fasting (63). This gene also plays a role in cellular responses to hypoxia, oxygen supply and thermogenic metabolism. Other genes, EPAS1 (endothelial PAS domain containing protein 1) and EGLN1 (Egl-9 family hypoxia inducible factor 2) have previously been highlighted as being involved in the physiological response to oxygen depletion in ancient populations (64). Indeed, tolerance of lower 
oxygen availability was observed in modern Andean and Tibetan people who have hemoglobin with adapted oxygen affinities $(65,66)$. When the EPAS1 gene was identified in Den DNA it was proposed that the capacity of Tibetan people to thrive in low-oxygen or high-altitude conditions was possibly inherited through introgression of Den-like DNA (64). MST1 is duplicated in Den D3, all $H n$ and Mesolithic $H s$ individuals. MST1 is not duplicated in Den D11, the hybrid of a Neandertal mother and Denisovan father from the Altai Mountains, or in the early $H s$.

PDPR (Pyruvate dehydrogenase phosphatase regulatory subunit) is a gene involved in the metabolism of brown fat thermogenic adipocytes, which convert chemical energy to heat in homeothermic animals such as mammals, protecting the body from cold stress (67). Brown fat is vital in babies and in hibernators. PDPR duplication may have provided a way to accumulate sufficient brown fat to survive the very cold winters of MIS 3, particularly in newborns (68). Den D3, most $H n$ individuals and late $H s$ individuals have the PDPR gene duplication. Ust'Ishim, Peştera Muierii 1 and Mal'ta have only one copy like Les Cottés and Vindija 33.19 and hybrid Den D11, whose mother shares an ancestral lineage with Vindija 33.19 (26).

Adaptation to protein in food of animal origin. Genes involved in the digestion of dietary proteins are expected to be duplicated in individuals that are preferentially carnivores. PGA3/4/5 (Pepsinogen A, group 1) is a gene cluster encoding a protein precursor of the digestive enzyme pepsin, a member of the peptidase A1 family (endopeptidases) involved in the digestion of dietary proteins. The precursor is secreted by gastric chief cells and undergoes autocatalytic cleavage under acidic conditions to form the active enzyme. Specifically expressed in some tissues, the PGA3/4/5 cluster belongs to the set of invariant genes in human genomes that maintain their copy number across populations. Unsurprisingly, this gene was found with a positive differential CNV in EAH and $H s$, considered preferential carnivores $(11,69)$ compared to modern humans. The level of duplication is also high with 4 copies in Den D3, Den D11, Ust'ishim, Peştera Muierii 1, Mal'ta and Loschbour, while Altai Neandertal D5, and the two Hn from Mezmaiskaya and Spy94a each have 5 copies. This data is consistent with $H n$ having a high intake of meat as already suggested by isotopic signals in fossils $(8,69)$.

Digestion and satiety. Relating to eating behavior, we identified the NPY4R gene encoding the pancreatic polypeptide (PP) receptor Y4, which has been described as a satiety-stimulating receptor involved in blood circulation and digestion. There are four NPY-family receptors in humans and all of them are expressed in the brain, namely in the hypothalamic regions that are involved in the control of appetite and energy metabolism, and NPY4R is also expressed in the gastrointestinal tract. Indeed, since PP has been reported to be a potent appetite inhibitor, NPY4R is considered a strong candidate for a body-weight regulation gene (70). A study of NPY4R in relation to body mass index in obese patients noted a positive correlation between this gene duplication and waist circumference in the modern population. Three archaic human genomes, Altai Neandertal D5, Vindija 33.19 and Den D3, have two (haploid) copies of the NPY4R gene so a duplication probably occurred prior to the modern human-Hn/Den split (71). In agreement, our analysis shows that NPY4R displays a positive differential CNV trend in both $H n$ and $H s$ populations. Late Hn (Les Cottès Z4-1514, Goyet Q56.1 and Spy 94a) and Den D11 have lost their copies though.

A multidimensional genetic space defined by CNV. Based on the CNV of the 11 genes, we visualized and compared the 16 genomes by plotting them in an 11-dimensional space, where each dimension corresponds to a gene. Formally, we represent a genome of an individual with its CNV 
profile as described by the relevant column in Table 1A. In this multidimensional space, two individuals are close when their CNV profiles are similar. To aid visualization, we reduced the space by principal component analysis (PCA) (72). The PCA projection (Figure 3) guarantees the largest divergence between the points through an optimized linear combination of the 11 original dimensions (see Method) with the modern human hg19 profile included.

The CNV data clearly separate $H n$ from $H s$ (Figure 3A) and group $H s$ with the modern human hg19. The hybrid Den D11 localizes close to $H s$ and Den 3 close to $H n$, showing a different CNV profile. Classification based on geographical origin (Figure 3B) or time period (Figure 3C) shows coherent subgroupings. Comparing CNV profiles of the individuals living in the same geographical area (Table 1B) illustrates how they are close in the high-dimensional space even when they belong to very different time periods. For instance, Mezmaiskaya 1 and Mezmaiskaya 2 both lived in Eastern Europe (Caucasus) and their very similar CNV profiles (Table 1B) brings them close together in the CNV space (Figure 3B, pink dots), even though they were not contemporary, living in $\mathrm{T} 2$ and $\mathrm{T} 4$ respectively.

Analysis of the PCA axes reveals that the most important factors explaining the first dimension of the CNV projection separating $H n$ from $H s$, are genes involved in lipid metabolism, ACOT1, CLPS and CYP2D6, and to a minor yet statistically significant extent, the gene SULT1A3/4 involved in carbohydrate digestion, and the gene MST1 involved in cold stress metabolism (Figure 3D). The second principal component is mainly explained by the protein metabolism gene cluster PGA3/4/5 and the satiety-stimulating receptor gene NPY4R and, to a lesser extent, by lipid metabolism (LPA) and carbohydrate metabolism (SULT1A3/4). The third principal component of the CNV space is mainly accounted for by genes involved in liver lipid/brown fat metabolism (PDPR, MST1), satiety-stimulation (NPY4R), carbohydrate metabolism (AMY1A/B/C) and protein metabolism (PGA3/4/5). Interestingly, carbohydrate metabolism contributes to all three principal components in a statistically significant manner, while the other metabolisms contribute to at most two dimensions.

To summarize, our analysis of the 11 genes primarily involved in digestive functions and displaying a differential copy number provides an unprecedented basis from which to deduce the adaptive changes between EAHs and $H s$ regarding dietary strategies. The crucial role of four different metabolic processes is highlighted that could influence the behavior of ancestral populations across species and suggests that the 11 genes can be used as markers for changes in dietary adaptation. The CNV genetic trend (Table 1A) points to lipid metabolism as being crucial for $H n$, while efficiency in carbohydrate metabolism influences the diet of Hs. Liver lipid metabolism, protein metabolism and satiety stimulation receptors must have been important for both $H n$ and $H s$ compared to modern humans and were probably already present in the common ancestral lineage. 


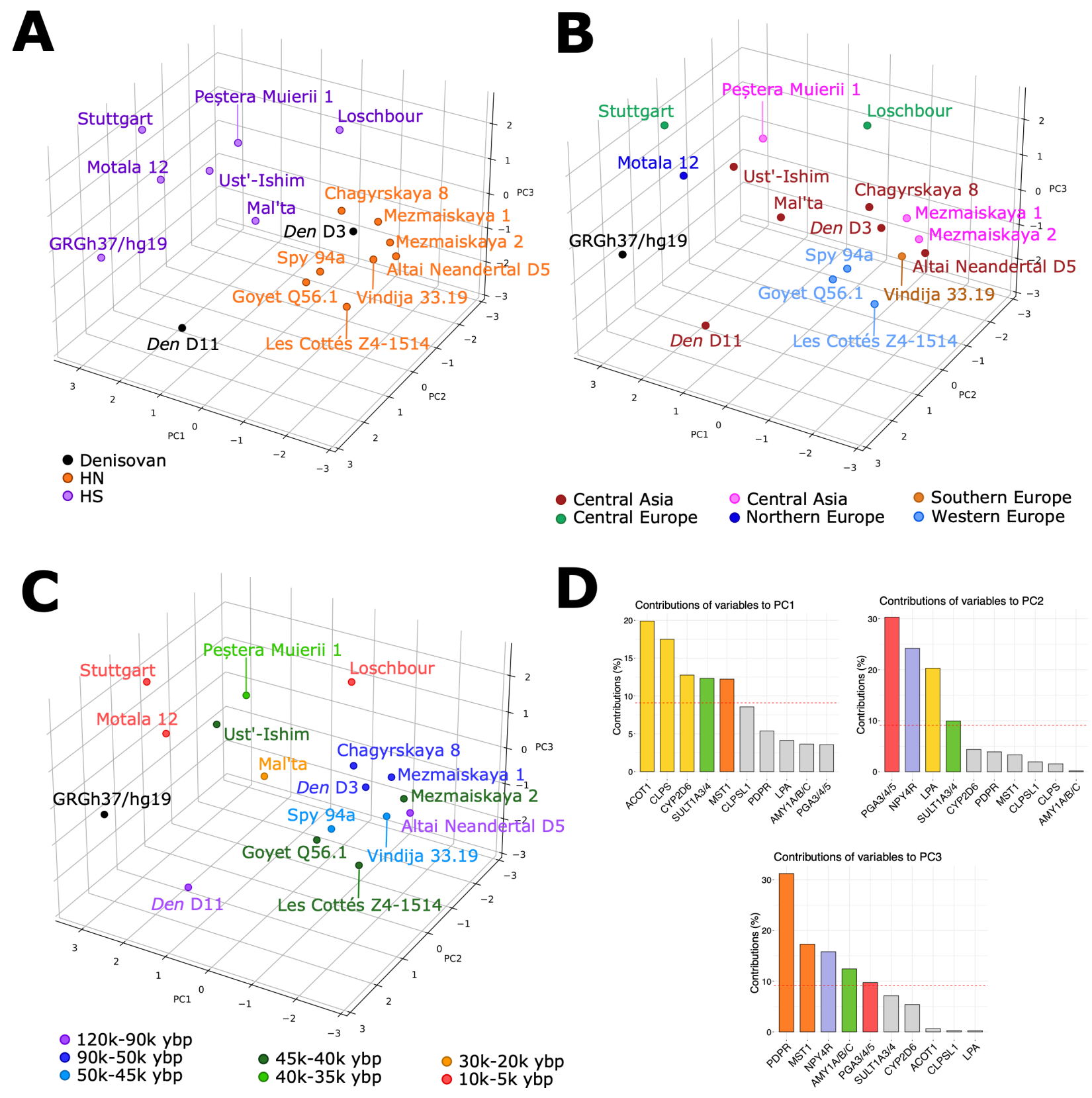

Figure 3. Comparative CNV analysis of $\mathrm{Hn}$, Den and $\mathrm{Hs}$ living in the European belt. Sixteen $H n$, Den and $H s$ individuals are represented in a three-dimensional space obtained by PCA from the 11-dimensional space defined from gene CNV (see Methods). The modern consensus genome GRGh37/hg19 is also plotted. A. View of the 3D space where individual CNV is plotted (points) with respect to human populations $H n$ (brown), Den (black), and $H s$ (purple). B and $\mathbf{C}$ show the same data as in A but individuals are grouped differently. B. Individuals are shown with respect to their geographical origin. C. Individuals are plotted with respect to time periods. D. Contributions of factors for the definition of each principal component of the 3D space, obtained by PCA. Colored bars indicate important contributions from $\mathrm{CNV}$ in genes acting in the four overarching metabolic processes (colors as in Table 1). 


\section{Discussion}

In this study, we explored 16 complete ancient genomes to identify trends in CNV of genes for the three human populations present during Late Pleistocene in the vast Eurasian territory - Hn, Den and early $H s$. By analysing a large number of published full genomes for CNV, our study significantly extends the list of genes identified as having an unusual copy number in archaic genomes. We focused on genes involved in food digestion and metabolism to unfold the complexity of nutritional adaptation among the three human populations sharing the same environmental conditions in Eurasia at the end of MIS 4 and during MIS 3. By comparing CNV at the population level, new data has been generated that provide evidence of different adaptive nutritional pathways potentially underlying the dietary habits of the three human populations. These CNV data contribute novel information that cannot be obtained from the fossils and archeological records. Nevertheless, it should be noted that functional complexity, epigenetic regulation, and microbiotic interaction make it difficult to define the precise role of these genes in the metabolic activities, even for modern human populations.

Unsupervised identification of genes presenting common CNV trends. The 11 genes identified in the unsupervised approach have specific functions in four overarching metabolic processes. Remarkably, each of the four metabolic process groups includes genes that show either a positive or a negative CNV trend for a population. In our view, this is a strong indication that an adaptive force acted on the duplication of these genes in archaic populations, modifying the capacity of the metabolic process with consequences on dietary habits and adaptation to different life conditions. From our data, we observe that the earliest individuals in a population may exhibit gene copy numbers that are different from chronologically later individuals, for instance, for NPY4R and AMY1A/B/C in $H n$ genomes and for MST1 and PDPR in $H s$ genomes. Chronological trends within populations can be clarified as more genomes become available to analyze.

Genomically distinct metabolisms in ancient human populations. Due to the limited number of available genomes where the estimation of CNV was possible (18), we mainly focused on $H n$ and $H s$, although we made inferences for the two Den hominins whenever possible. The different $\mathrm{CNV}$ trends observed for $H n$ and $H s$ reflect that these hominins relied on different diets and align well with adaptation needed for their known evolutionary histories. The genes involved in efficient digestion and metabolism of dietary carbohydrates (AMY1A/B/C, SULT1A3/4) appear important for $H s$ while genes involved in lipid metabolism (ACOT1, CYP2D6, CLPS, CLPSL1, LPA) show positive trends for $H n$. Conversely, genes involved in the breakdown of proteins (PGA3/4/5, pepsin) and liver lipid metabolism (MST1 and PDPR) appear to be of importance for both $H n$ and early $H s$, both displaying a positive trend compared to the modern reference human genome GRCh37/hg19. The CNV of these genes may have made efficient lipid and protein metabolism/catabolism possible as a response to the cold stress experienced during MIS 3, moderating the susceptibility to ketosis in adults (14, p. 256). SULT1A3/4, involved in carbohydrate metabolism and in thyroid hormone activity, might have contributed to this adaptive trend by increasing cold-induced thermogenesis, to avoid the effects of "polar $\mathrm{T}_{3}$ syndrome" (73). The involvement of thyroid hormone in vital pathways warrants further investigation in relation to SULT1A3/4 gene cluster emergence, chronology and duplication. Overall, the CNV of genes involved in oxygen and lipid metabolism (and catabolism) form a valuable dataset with which to interpret the adaptation to temperate and cold ecosystems. The evidence could be used to deduce 
or confirm the organismal thermal ranges and their implications for differential nutritional strategies between the three populations.

Broadening the number of genomes investigated since the pivotal studies by Perry and co-authors $(6,7)$ provides further evidence that $\mathrm{AMY} 1 \mathrm{~A} / \mathrm{B} / \mathrm{C} \mathrm{CNV}$ played a vital role in equipping $H s$ to digest and transform dietary carbohydrates and thus benefit from caloric energy for cost-efficient homeostasis. It is relevant here to estimate when the AMY1A/B/C duplication occurred (15-17) as the earliest $H s$ in Eurasia, represented in this work by the Ust'-Ishim fossil, already bore three copies per haploid genome. An ancient AMY1A/B/C duplication matches the archaeological evidence and provides molecular corroboration that cooked rhizomes could have been consumed as early as $170 \mathrm{ybp}$ in South African caves (74), dovetailing with the occurrence of ground stones used to mechanically tenderize roots and tubers during the Early Upper Paleolithic in Eurasia (7579). Based on our data, it is parsimonious to consider that the emergence of an efficient strategy for starch digestion and metabolism is related to the $H s$ lineage already carrying the AMY1A/B/C gene duplication when they moved out of Africa, thus well before crop domestication $(15,17)$. On the other hand, our findings show that there is no evidence of $\mathrm{AMY} 1 \mathrm{~A} / \mathrm{B} / \mathrm{C}$ duplication in $H n$, for example, neither in Altai Neandertal (D5, dated 120k ybp) nor Chagyrskaya 8 (dated 80-60k ybp; Tables 1A and S2). Thus, some duplication events must have occurred after the EAH lineages split $(15,17)$ and we argue that this was due to the nutrition changes faced by $H s$ while roaming across African territories compared to temperate and cold environments where $H n$ and Den were used to foraging their prey.

New information on the $\boldsymbol{H n}$ diet. Our work highlights that $H n$ metabolism was more efficient in the digestion of lipids and proteins than carbohydrates. The genetic adaptation to fat and protein metabolism is an archaic pattern present in $\mathrm{Hn}$, who were adapted to temperate and cold climates. The CNV trend of genes involved in fat and protein metabolism (Table 1) undoubtedly emerged during the cold period (even before the timing of Altai Neandertal D5, the oldest Neandertal in our sample) when the $H n$ differentiated. As already pointed out for $H n$ anatomical characteristics (i.e., their low stature resulting from adaptation to the cold; 80, 81, 10) and their cold adaptation genes $(82,83)$, these adapted traits persisted even during interglacial periods, putatively due to the low genetic diversity of $H n(84,27,30)$. We found a trend in $H n$, going from the oldest Altai Neandertal to the later Spy I, confirming independently what has already been noted from fossil analysis — that Altai Neandertals were highly carnivorous (85-87) while Spy I added some starchy tubers to his diet (76). The CNV population trend of genes involved in fat and protein metabolism could even explain the peculiar skeletal morphology observed in Hn. A large bellshaped lower thorax and a wide pelvis shaped to accommodate the larger liver and kidneys are an adaptation to a high fat, high protein diet. These organs are highly solicited for lipid and protein metabolism so the genetic evidence coincides with the specific anatomy (88) and high energy needs of $H n(89,90,10)$.

$H n$ shows a negative trend for genes involved in dietary carbohydrate digestion compared to the modern human reference genome and $H s$. Nonetheless, two late $H n$ in our sample, Les Cottés ZA1514 and Goyet Q56.1, have 3 copies of AMY1A/B/C like the human reference genome, indicative of a less restricted foraging strategy being adopted by $H n$ due to the different environmental conditions $(76,14,9,91)$. A plausible interpretation is that some late $H n$ may have interbred with early dispersals of $H s$. 
The duplication of the PDPR gene in EAHs appears as an adaptive response to the cold Eurasian steppe climate. The lack of duplication in early $H s$ living in the same climatic conditions might be explained by the coupling of AMY1A/B/C and SULT1A3/4 gene clusters that would also have increased the thermogenesis response.

CYP2D6, CLPS, CLPSL1, and LPA positive CNV trends in Hn have been reported to relate to fasting hepatic FA metabolism because they control the lipids balancing oxidative flux and capacity (54). Fats can be digested to form fatty acids, and proteins can be partially transformed into glucose through gluconeogenesis $(92,93)$. Gluconeogenesis is an efficient pathway to allow glucose to directly entering the bloodstream, to fuel the high demand of organs, notably the brain, which in $H n$ is very large (around $1450 \mathrm{cc}$, much larger than the average brain today; 10). Although gluconeogenesis demands much energy (94), within a highly carnivorous regime it can (i) provide glucose to the brain for a limited time, and (ii) become a profitable pathway to maximize the benefit of protein intake $(95,5)$. In particular, it reduces the amount of nitrogen to avoid protein poisoning $(92,5,50)$ and limit ketosis in adults $(14)$.

Regarding the beneficial role of FA in the diet, it is well known that nuts have always been present in human diet as shown by the Acheullian site in Israel $700 \mathrm{kyrs}$ ago (96). In certain geographical regions, it is possible that $H n$ relied on a diet much richer in omega-3 present in wild fish (97). Coherent with an indirect high intake of animal fat from herbivores, and of omega- 6 fatty acids from vegetable oils, $\mathrm{Hn}$ and Den populations show a positive CNV trend for the gene CYP2D6, involved in the arachidonic acid metabolic process. FA are consumed at higher levels in diets incorporating more animal proteins and are critical for brain development, brain metabolism, and inflammatory responses (49).

A glance into the Den diet. The CNV analysis was done on only two Den individuals, so it is difficult to see a trend, particularly as Den D3 and Den D11 do not have the same CNV profile. While Den D3 shows an Hn-like trend, Den D11 - the young hybrid female with an Hn mother and Den father - is much closer to the modern human. Indeed, the CNV profile for Den D11 includes many genes with the same copy number as the equivalents in modern humans that have evolved in warm environmental conditions. It is acknowledged that Den in Altai are a western extension of a much larger population originating in central and southwestern Asia $(98,26)$. Hence, we can hypothesize that Den D11 shows stronger genetic signs of adaptation to southwestern Asia than Den D3 as the climate was more similar to where $H s$ evolved, already adapted to carbohydrate-rich diets $(6,15)$. Further analyses will be possible when more Den genomes become available.

A new picture of the $\boldsymbol{H s}$ diet. If it holds true that plants were part of the hominin diet for millions of years (99), the physiology involved in the efficient digestion and transformation of dietary carbohydrates took time to adapt, notably through the redesigning of core metabolic and physiological processes $(100,13)$. This took place during the evolution of $H s$ in Africa, where under favorable environmental conditions, they may have experienced the gathering and transformation of plants rich in starch $(101,74)$. Our study provides three main contributions linked to dietary carbohydrate metabolism. First, $H s$ and the modern genome GRCh37/hg19 have a higher copy number for the AMY1A/B/C and the SULT1A3/4 gene clusters compared to Hn and Den. Conversely, we find no enhanced CNV in $H s$ for genes involved in lipid metabolism compared to $H n$, although LPA shows a positive trend in both populations. Second, our data are consistent with the proposed early emergence of AMY1 coupling - between 273-475 ybp - after 
the divergence from $H n$ and well before crop domestication (15-17). Third, we identified the role of the SULT1A3/4 and AMY1A/B/C gene clusters as main contributing factors explaining the three dimensions of the CNV space of individuals in Figure 3. These three results prompt new questions centered on the importance of dietary carbohydrates in the diet of archaic humans and, in particular, in $H s$.

Conclusion. The different CNV trends observed for $H n$ and $H s$ reflect that these hominins relied on different sources of energy in their diets. Our unsupervised analysis of the CNV of multiple genes adds new lines of evidence that confirm the biological adaptation of $\mathrm{Hn}$ to a narrowspectrum diet and highlight the genetic changes facilitating liver lipid and protein catabolic pathways in both $H n$ and $H_{s}$ living in the same nutritional environment of the cold Eurasian steppe. The increasing duplication of AMY $1 \mathrm{~A} / \mathrm{B} / \mathrm{C}$ and SULT1A3/4 genes evident in $H s$ is consistent with broad-based foraging strategies potentially benefiting from the use of grinding stones to transform starch-rich storage organs of plants before the Neolithic. Different nutritional strategies among the three human populations inhabiting the temperate and cold latitudes during the crucial timing of their overlapping could have given $H s$ better fitness leading to a demographic advantage that allowed them to conquer the continent.

\section{Materials and Methods}

An unsupervised procedure for the identification of genes involved in digestion presenting a CNV trend within an ancient population. The methodology is based on several distinct computational steps:

1. Selection of all available genomes that could allow for an estimation of the haploid gene copy number.

2. Estimation of the haploid gene copy number for all genes of the genomes identified in 1 .

3. Selection of those genes whose number of haploid copies in $H n, H s$ or Den is higher or lower than in the modern reference genome GRCh37/hg19 for more than the half of individuals in the population. This means that a selected gene should display a differential $C N V$ for at least 5 individuals in $H n$ or at least 4 individuals in $H s$ or both individuals in Den.

4. Selection of the final set of genes based on Gene Ontology functional annotation and principal expression in digestive tissues.

Steps 1, 2 and 4 are detailed below.

After the four steps identifying the 11 genes, we used the notion of $C N V$ trend to analyze them within more than one population. Formally, a gene has a positive/negative $C N V$ trend in a population if its gene copy number is either greater/smaller than that of the modern reference genome for at least half of the individuals in the population (4 of the $8 H n$ genomes, 3 of the $H s 6$ genomes, or both Den genomes). This criterion is weaker than the one used to select genes (see 3 above) and it is aimed to highlight the tendency for a gene to have more or fewer CNVs than the modern reference genome GRCh37/hg19 within a population. The gene MST1, for instance, displays positive CNV trends for both $H n$ and $H s$ even though it would only be selected because of its differential $\mathrm{CNV}$ in the $H n$ population. Also, the gene cluster AMY1A/B/C was selected because of its negative differential $\mathrm{CNV}$ in $H n$, but in the $H s$ population there is an opposite tendency in $\mathrm{AMY} 1 \mathrm{~A} / \mathrm{B} / \mathrm{C}$ duplication that is picked up by the CNV trend criterion. Table 1 and Table S5 show the 11 aforementioned genes, their estimated copy number (rounded and not, respectively) for the 16 ancient genomes and the $\mathrm{CNV}$ trends for the three populations. 
Genome selection for genome-wide analysis. Among all publicly available human ancient genomes, we identified all genomes presenting a minimum number of features that allowed us to properly perform a CNV analysis (see Table S1). Specifically, we considered genomes that:

1. present a $1 \mathrm{x}$ minimum coverage of the human reference sequence, with available alignments with the modern $H s$ genome assembly GRCh37/hg19.

2. have been affected less than $5 \%$ by contamination from modern human sequences

3. did not exclude sequences aligned with repetitive regions (that is, characterized by a MAPQ value of 0 ). The integration of such genomes would have required a re-run of the entire pipeline of mapping from raw sequences.

The three conditions allowed 16 archaic human genomes to be considered. They were retrieved from accession codes published in manuscripts before December 2020, to which we added the more recent genome of Peştera Muierii (July 2021); see Table S1 for downloading information.

It is worth mentioning that some very interesting genomes, although characterized by a sufficiently high coverage, were discarded for various reasons: the available alignment files for Anzick-1, Kostenki 14, Sunghir 1--4, and Sunghir 6 do not comprise repeated regions; LaBraña lacks data for chromosome 22; Den D2, Hohlenstein Stadel, and Scladina have low coverage and/or high contamination.

Data preprocessing. Ancient genomes are available as alignment files (in BAM format) of sequenced DNA fragments mapped on the GRC37/hg19 assembly in all publications. These sequence fragments commonly undergo several pre-processing steps such as error correction, merging of paired reads, mapping using BurrowsWheeler Aligner with parameters adjusted to ancient DNA (25), removal/collapsing of PCR duplicates, and possibly realignment around indels using Genome Analysis Toolkit. This procedure is performed individually, for all sequenced libraries, which are finally merged during the removal of PCR duplicates using the bamrmdup utility from biohazard-tools (https://bitbucket.org/ustenzel/biohazard-tools) preserving only those fragments marked as correctly mapped pairs. In case the available paired-end read libraries were not merged, we performed this step using Samtools (102). This way, we obtained a single (BAM) alignment file for each genome that we considered in our study.

Gene copy number estimation. It is well known that next-generation sequencing (NGS) technologies can introduce, to varying degrees, uneven coverage of reads resulting from GC bias (103). As our analysis of copy number variation is based on aligned reads and depth of coverage of specific regions, to correct the datasets for such biases is of utmost importance. We therefore used deepTools2 (104) to compute and correct GC-bias using Benjamini's method (105). More precisely, we used the utility computeGCBias with parameters effectiveGenomeSize $\mathrm{L}_{\mathrm{hg} 19}$ and -bl blacklist.bed to compute the GC-bias, where $L_{h g 19}$ is the ungapped length of placed scaffolds of the chromosome under consideration in GRCh37/hg19 reference genome (lengths are available in column "Placed scaffolds" of section "Ungapped lengths" at https:/www.ncbi.nlm.nih.gov/grc/human/data) and blacklist.bed refers to the ENCODE DAC Blacklisted Regions (106) (i.e. a comprehensive set of regions in the human genome that have anomalous, unstructured, high signal/read counts in NGS experiments). Finally, alignment files were corrected for GC-bias using the utility correctGCBias with parameter--effectiveGenomeSize L L

Given a genome G, the depth of coverage (average or per-base) was computed using mosdepth (107) with default parameters on the GC-bias corrected alignment files. More precisely, given a chromosome $c h r_{\mathrm{i}}$ where $i$ $\in\{1, \ldots, 22\}$, its average depth of coverage $C^{i}$ was computed as

$$
C^{i}=\frac{\sum_{j \in c h r_{i}} d o c_{j}^{i}}{L_{h g 19}^{i}}
$$


where $d o c_{j}^{i}$ is the depth of coverage computed by mosdepth at position $j$ of chromosome $i$, and $L_{h g 19}^{i}$ is the ungapped length of chromosome $i$ in the GRCh37/hg19 reference genome. As analyzed datasets involve male and female individuals, we decided to restrict the copy number variation analysis to autosomes.

A set of protein coding genes $G$ for GRCh37/hg19 was retrieved from ENSEMBLE (version 98) (108) and genes overlapping any of the ENCODE DAC Blacklisted Regions (106) were excluded from the analysis, regardless of the length of the overlap.

The coverage $C_{g}^{i}$ of a gene $g$ annotated on chromosome $i$ is computed as

$$
C_{g}^{i}=\frac{\sum_{j \in g} d o c_{j}^{i}}{L_{g}}
$$

where the depth of coverage $d o c_{j}^{i}$ is computed exclusively at positions $j$ of the gene $g$ of length $L_{g}$. Hence, we estimate the haploid copy number of a gene $g$ as $C_{g}^{i} / C^{i}$.

Finally, human paralog genes were clustered together above $80 \%$ identity (e.g., the three AMY1 copies are merged and only AMY1B is mentioned in our analysis) and the estimated copy numbers of "clustered genes" were added together to define the copy number of the gene which is the representative of the cluster. In Table 1, this clustering procedure generated the "gene clusters" AMY1A/B/C, SULT1A3/4 and PGA3/4/5.

Estimation of the absence of the gene ACOT1. We estimated that the ACOT1 gene is not present in Hn, Den D3 and Loschbour genomes. In this respect, notice that in the Altai Neandertal D5 genome, ACOT1 coverage is estimated at 0.22 (Table S5), which can be explained by the presence of the paralogous gene ACOT2. The two genes are known to have the same function, ACOT1 acting in the cytosol and ACOT2 in mitochondria (53). The ACOT1 paralog ACOT2 is a protein of 483 amino acids that contains a 62 amino acid leader sequence at the N-terminal that targets the protein to mitochondria. The ACOT1 protein is shorter than ACOT2 and the alignment of its 421 amino acids to ACOT2 shows 98.6\% sequence identity, with only 5 amino acids being different. ACOT2 coverage is estimated at 0.86 , confirming the absence of the ACOT1 copy in the genome. The same applies to the Den D3 and Loschbour genomes. See (52) for a general description of type 1 and 2 ACOT genes.

Functional annotation of genes based on GO terms. DAVID $(37,38)$ was used to functionally annotate genes whose estimated haploid copy number differed from GRCh37/hg19 in at least one ancient genome. Hence, we could associate each annotated gene to a "generic" functional category (i.e. GO slims) according to the specific GO-term annotation. The result is reported in Table S3.

Principal tissue expression of genes. The Human Protein Atlas (HPA; 39) was used to identify the tissues where genes were principally expressed. HPA was accessed online at https://www.proteinatlas.org/ and genes were selected if their principal expression is in organs of the digestive apparatus: stomach, intestine, liver, pancreas, gall bladder, salivary gland, and appendix. The result is reported in Table S4.

The fossils, geographical regions and time period. The fossils/genomes (Table S2) of the 16 individuals have been associated to their geographical region and time period (Figure 3). For this, we defined six different regions of the Asian European belt, from the most eastern to the most western: Central Asia, Eastern Europe, Central Europe, Northern Europe, Southern Europe, Western Europe. These geographic areas were identified according to (109) and (110), modelling eco-geographical and morphological data on the Neandertalian territory and variability of mtDNA. To take ecological diversity into account, we added Central Asia and Central Europe to the geographic area already defined in these two publications. Indeed, since the latter studies, new evidence for the great $\mathrm{Hn}$ extension in Central Asia has been collected (from Altai Neandertal and 
Chagyrskaya caves). Also, we reduced the "Northern Europe" area by splitting it into two regions and adding an eastern one, named "Central Europe", where the climate was different. This geographical division is used here for $H n$ and $H s$. We considered seven time periods: $120 \mathrm{k}-90 \mathrm{k}$ ybp, $90 \mathrm{k}-50 \mathrm{k}$ ybp, 50k-45k ybp, 45k-40k ybp, 40k-35k ybp, 30k-20k ybp, and 10k-5k ybp. Regions and time periods were coded as integers for PCA analysis.

Individuals plotted in the $\mathbf{C N V}$ multidimensional space. We represented individuals in a multidimensional space by using gene CNVs as real-valued features. Plots were drawn with the R package ggplot, and several geom_point functions. We used the aggregate function from the stats package to compute centroids.

Principal component analysis (PCA). PCA is a well-known computational method used in exploratory data analysis and for making predictive models (72). It is commonly used for dimensionality reduction when the number of features (or dimensions) in a given dataset is too high. We used PCA to project each data point onto only the first few principal components to obtain lower-dimensional data while preserving as much of the variation as possible. The first principal component can be defined as a direction that maximizes the variance of the projected data. The 2 nd principal component can be taken as a direction orthogonal to the first principal component that maximizes the variance of the projected data, and so on. Thus, a new dimensional system, where each dimension relies on a combination of the initial dimensions of the data, is generated.

We reduced the 11 dimensions of the high-dimensional space where individuals are represented by their gene CNVs. In Figure 3, the position of the reference genome GRGh37/hg19 was also plotted for comparison.

The function prcomp from the $\mathrm{R}$ package stats was used with the parameter 'scale' was set to TRUE. The contribution of each variable (as a percentage) to the first three principal components was evaluated using the function fviz_contrib and visualized as a barplot. The dotted red line is the expected average contribution. A variable with a higher contribution than this is considered important, and was highlighted in the Figure 3d. For the visualization, we used the function plot_ly of the R package plotly. With this function the main dimensions of the PCA to be represented in the n-dimensional space can be chosen. We chose to represent the first three principal components. 


\section{References}

1. T. Rito, D. Vieira, M. Silva, E. Conde-Sousa, L. Pereira, P. Mellars, M. Richards, P. Soares, A dispersal of Homo sapiens from southern to eastern Africa immediately preceded the out-of-Africa migration. Scientific reports 9(1), 1-10 (2019).

2. D.W. Bird, J.F. O'Connell, Behavioral Ecology and Archaeology. Journal of Archaeological Research 14, 143-188 (2006).

3. G. Nantel, Carbohydrates in human nutrition. Food Nutrition and Agriculture/ANA 24, 6-10 (1999).

4. J. Mann, J.H. Cummings, H.N. Englyst, T. Key, S. Liu, G. Riccardi, C., Summerbell, R., Uauy, R.M., van Dam, B., Venn, H.H., Vorster, M. Wiseman, FAO/WHO Scientific Update on carbohydrates in human nutrition: conclusions. European Journal of Clinical Nutrition 61 (Suppl 1), S132-S137 (2007).

5. J.D. Speth, Paleoanthropology and archaeology of big-game hunting (Springer, New York, 2012).

6. G.H. Perry, N.J. Dominy, K.G. Claw, A.S. Lee, H. Fiegler, R. Redon, J. Werner, F.A. Villanea, J.L. Mountain, R. Misra, N.P. Carter, C. Lee, A.C. Stone, Diet and the evolution of human amylase gene copy number variation. Nat. Gen. 39(10), 1256-1260 (2007).

7. G.H. Perry, L. Kistler, M.A. Kelaita, A.J. Sams, Insights into hominin phenotypic and dietary evolution from ancient DNA sequence data. J. Hum. Evol. 97, 55-63 (2015).

8. M.P. Richards, E. Trinkaus, Isotopic evidence for the diets of European Neanderthals and early modern humans. Proceedings of the National Academy of Sciences 106(38), 16034-16039 (2009).

9. H. Bocherens, D.G. Drucker, S. Madelaine, Evidence for a $15 \mathrm{~N}$ positive excursion in terrestrial foodwebs at the middle to upper Palaeolithic transition in south-western France: implication for early modern human palaeodiet and palaeoenvironment. J. Hum. Evol. 69, 31-43 (2014).

10. S.E. Churchill, Thin on the ground: Neandertal biology, archeology, and ecology (John Wiley \& Sons, 2014).

11. D.G. Drucker, Y.I. Naito, S. Péan, S. Prat, L. Crépin, Y. Chikaraishi, N. Ohkouchi, S. Puaud, M. Lázničková-Galetová, M. Patou-Mathis, A. Yanevich, H. Bocherens, Isotopic analyses suggest mammoths and plants in the diet of the oldest anatomically modern humans from far South East Europe. Scientific Reports 7(1), 1-10 (2017).

12. M.T. Buckley, F. Racimo, M.E. Allentoft, M.K. Jensen, A. Jonsson, H. Huang, F. Hormozdiari, M. Sikora, D. Marnetto, E. Eskin, M.E. Jørgensen, N. Grarup, O. Pedersen, T. Hansen, P. Kraft, E. Willerslev, R. Nielsen, Selection in Europeans on Fatty Acid Desaturases Associated with Dietary Changes. Mol. Biol. Evol. 34(6), 1307-1318 (2017).

13. P.J. Butterworth, F.J. Warren, P.R. Ellis, Human $\alpha$-amylase and starch digestion: An interesting marriage. Starch/Starke 63, 395-405 (2011).

14. K. Hardy, J. Brand-Miller, K.D. Brown, M. Thomas, L. Copeland, The importance of dietary carbohydrate in human. Quat. Rev. Biol. 90(3), 251-268 (2015).

15. C.E. Inchley, C.D.A. Larbey, N.A.A. Shwan, L. Pagani, L. Saag, T. Antão, G. Jacobs, G. Hudjashov, E. Metspalu, M. Mitt, C.A. Eichstaedt, B. Malyarchuk, M. Derenko, J. Wee, S. Abdullah, F-X. Ricaut, M. Mormina, R. Mägi, R. Villems, M. Metspalu, M.K. Jones, J.A.L. Armour, T. Kivisild, Selective sweep on human amylase genes postdates the split with Neanderthals. Sc. Rep. 6, 37198, (2016).

16. R.N. Carmody, M. Dannemann, A.W. Briggs, B. Nickel, E.E. Groopman, R.W. Wrangham, J. Kelso, Genetic Evidence of Human Adaptation to a Cooked Diet. Genome Biol. Evol. 8(4), 1091-1103 (2016).

17. S. Mathieson, I. Mathieson, FADS1 and the Timing of Human Adaptation to Agriculture. Mol. Biol. Evol. 35(12):2957-2970 (2018).

18. D.F. Conrad, D. Pinto, R. Redon, L. Feuk, O. Gokcumen, Y. Zhang, J. Aerts, T.D. Andrews, C. Barnes, P. Campbell, T. Fitzgerald, M. Hu, C.H. Ihm, K. Kristiansson, D.G. MacArthur, J.R. MacDonald, I. Onyiah, A.Wing Chun Pang, S. Robson, K. Stirrups, A. Valsesia, K. Walter, J. Wei, The Wellcome Trust Case Control Consortium, C. Tyler-Smith, N.P. Carter, C. Lee, S.W. Scherer, M.E. Hurles, Origins and functional impact of copy number variation in the human genome. Nature 464, 704-712 (2010).

19. R.C. Iskow, O. Gokcumen, C. Lee, Exploring the role of copy number variants in human adaptation. Trends Genet. 28(6), 245-257 (2013).

20. X. Nuttle, G. Giannuzzi, M.H. Duyzend, J.G. Schraiber, I. Narvaiza, P.H. Sudmant, O. Penn, G. Chiatante, M. Malig, J. Huddleston, C. Benner, F. Camponeschi, S. Ciofi-Baffoni, H.A. Stessman, M.C. Marchetto, L. Denman, L. Harshman, C. Baker, A. Raja, K. Penewit, N. Janke, W. Joyce Tang, M. Ventura, L. Banci, F. Antonacci, J.M. Akey, C.T. Amemiya, F.H. Gage, A. Reymond, E.E. Eichler, Emergence of a Homo sapiens-specific gene family and chromosome 16p11.2 CNV susceptibility. Nature 536(7615), 205-209 (2016).

21. D. Carpenter, L.M. Mitchell, J.A. Armour, Copy number variation of human AMY1 is a minor contributor to variation in salivary amylase expression and activity. Human genomics 11(1), 1-6 (2017).

22. A.M. Rice, A. McLysaght, Dosage-sensitive genes in evolution and disease. BMC Biology 15(1), 1-10 (2017).

23. S.H. Almal, H. Padh, Implications of gene copy-number variation in health and diseases. Journal of human genetics 57(1), 613 (2012).

24. X. Shao, N. Lv, J. Liao, J. Long, R. Xue, N. Ai, D. Xu, X. Fan, Copy number variation is highly correlated with differential gene expression: a pan-cancer study. BMC medical genetics 20(1), 1-14 (2019).

25. M. Meyer, M. Kircher, M.T. Gansauge, H. Li, F. Racimo, S. Mallick, J.G. Schraiber, F. Jay, K. Prüfer, C. de Filippo, P.H. Sudmant, C. Alkan, Q. Fu, R. Do, N. Rohland, A. Tandon, M. Siebauer, R.E. Green, K. Bryc, A.W. Briggs, U. Stenzel, J. Dabney, J. Shendure, J. Kitzman, M.F. Hammer, M.V. Shunkov, A.P. Derevianko, N. Patterson, A.M. Andrés, E.E. Eichler, 
M. Slatkin, D. Reich, J. Kelso, S. Pääbo, A high-coverage genome sequence from an archaic Denisovan individual. Science 338(6104), 222-226 (2012).

26. V. Slon, F. Mafessoni, B. Vernot, C. de Filippo, S. Grote, B. Viola, M. Hajdinjak, S. Peyrégne, S. Nagel, S. Brown, K. Douka, T. Higham, M.B. Kozlikin, M.V. Shunkov, A.P. Derevianko, J. Kelso, M. Meyer, K. Prüfer, S. Pääbo, The genome of the offspring of a Neanderthal mother and a Denisovan father. Nature 561(7721), 113-116 (2018).

27. K. Prüfer, F. Racimo, N. Patterson, F. Jay, S. Sankararaman, S. Sawyer, A. Heinze, G. Renaud, P.H. Sudmant, C. de Filippo, H. Li, S. Mallick, M. Dannemann, Q. Fu, M. Kircher, M. Kuhlwilm, M. Lachmann, M. Meyer, M. Ongyerth, M. Siebauer, C. Theunert, A. Tandon, P. Moorjani, J. Pickrell, J.C. Mullikin, S.H. Vohr, R.E. Green, I. Hellmann, P.L.F. Johnson, H. Blanche, H. Cann, J.O. Kitzman, J. Shendure, E.E. Eichler, E.S. Lein, T.E. Bakken, L.V. Golovanova, V.B. Doronichev, M.V. Shunkov, A.P. Derevianko, B. Viola, M. Slatkin, D. Reich, J. Kelso, S. Pääbo, The complete genome sequence of a Neanderthal from the Altai Mountains. Nature 505(7481), 43-49 (2014).

28. F. Mafessoni, S. Grote, C. de Filippo, V. Slon, K.A. Kolobova, B. Viola, S.V. Markin, M. Chintalapati, S. Peyrégne, L. Skov, P. Skoglund, A.I. Krivoshapkin, A.P. Derevianko, M. Meyer, J. Kelso, B. Peter, K. Prüfer, S. Pääbo, A high-coverage Neandertal genome from Chagyrskaya Cave. Proceedings of the National Academy of Sciences 117(26), 15132-15136 (2020)

29. Q. Fu, H. Li, P. Moorjani, F. Jay, S.M. Slepchenko, A.A. Bondarev, P.L.F. Johnson, A. Aximu-Petri, K. Prüfer, C. de Filippo, M. Meyer, N. Zwyns, D.C. Salazar-García, Y.V. Kuzmin, S.G. Keates, P.A. Kosintsev, D.I. Razhev, M.P. Richards, N.V. Peristov, M. Lachmann, K. Douka, T.F.G. Higham, M. Slatkin, J-J. Hublin, D. Reich, J. Kelso, T.B. Viola, S. Pääbo, Genome sequence of a 45,000-year-old modern human from western Siberia. Nature 514(7523), 445-449 (2014).

30. K. Prüfer, C. de Filippo, S. Grote, F. Mafessoni, P. Korlević, M. Hajdinjak, B. Vernot, L. Skov, P. Hsieh, S. Peyrégne, D. Reher, C. Hopfe, S. Nagel, T. Maricic, Q. Fu, C. Theunert, R. Rogers, P. Skoglund, M. Chintalapati, M. Dannemann, B. J. Nelson, F.M. Key, P. Rudan, Ž. Kućan, I. Gušić, L.V. Golovanova, V.B. Doronichev, N. Patterson, D. Reich, E.E. Eichler, M. Slatkin, M.H. Schierup, A.M. Andrés, J. Kelso, M. Meyer, S. Pääbo, A high-coverage Neandertal genome from Vindija Cave in Croatia. Science 358(6363), 655-658 (2017).

31. M. Hajdinjak, Q. Fu, A. Hübner, M. Petr, F. Mafessoni, S. Grote, P. Skoglund, V. Narasimham, H. Rougier, I. Crevecoeur, P. Semal, M. Soressi, S. Talamo, J-J. Hublin, I. Gušić, Ž. Kućan, P. Rudan, L.V. Golovanova, V.B. Doronichev, C. Posth, J. Krause, P. Korlević, S. Nagel, B. Nickel, M. Slatkin, N. Patterson, D. Reich, K. Prüfer, M. Meyer, S. Pääbo, J. Kelso, Reconstructing the genetic history of late Neanderthals. Nature 555(7698), 652-656 (2018).

32. E. Svensson, T. Günther, A. Hoischen, M. Hervella, A.R. Munters, M. Ioana, F. Ridiche, H. Edlund, R.C.van Deuren, A. Soficaru, C. de-la-Rua, M.G.Netea, M. Jakobsson, Genome of Peştera Muierii skull shows high diversity and low mutational load in pre-glacial Europe. Current Biology (2021).

33. M. Raghavan, P. Skoglund, K.E. Graf, M. Metspalu, A. Albrechtsen, I. Moltke, S. Rasmussen, T.W. Stafford Jr, L. Orlando, E. Metspalu, M. Karmin, K. Tambets, S. Rootsi, R. Mägi, P.F. Campos, E. Balanovska, O. Balanovsky, E. Khusnutdinova, S. Litvinov, L.P. Osipova, S.A. Fedorova, M.I. Voevoda, M. DeGiorgio, T. Sicheritz-Ponten, S. Brunak, S. Demeshchenko, T. Kivisild, R. Villems, R. Nielsen, M. Jakobsson, E. Willerslev, Upper Palaeolithic Siberian genome reveals dual ancestry of Native Americans. Nature 505(7481), 87-91 (2014).

34. I. Lazaridis, N. Patterson, A. Mittnik, G. Renaud, S. Mallick, K. Kirsanow, P.H. Sudmant, J.G. Schraiber, S. Castellano, M. Lipson, B. Berger, C. Economou, R. Bollongino, Q. Fu, K.I. Bos, S. Nordenfelt, H. Li, C. de Filippo, K. Prüfer, S. Sawyer, C. Posth, W. Haak, F. Hallgren, E. Fornander, N. Rohland, D. Delsate, M. Francken, J-M. Guinet, J. Wahl, G. Ayodo, H.A. Babiker, G. Bailliet, E. Balanovska, O. Balanovsky, R. Barrantes, G. Bedoya, H. Ben-Ami, J. Bene, F. Berrada, C.M. Bravi, F. Brisighelli, G.B.J. Busby, F. Cali, M. Churnosov, D.E.C. Cole, D. Corach, L. Damba, G. van Driem, S. Dryomov, J-M. Dugoujon, S.A. Fedorova, I.G. Romero, M. Gubina, M. Hammer, B.M. Henn, T. Hervig, U. Hodoglugil, A.R. Jha, S. Karachanak-Yankova, R. Khusainova, E. Khusnutdinova, R. Kittles, T. Kivisild, W. Klitz, V. Kučinskas, A. Kushniarevich, L. Laredj, S. Litvinov, T. Loukidis, R.W. Mahley, B. Melegh, E. Metspalu, J. Molina, J. Mountain, K. Näkkäläjärvi, D. Nesheva, T. Nyambo, L. Osipova, J. Parik, F. Platonov, O. Posukh, V. Romano, F. Rothhammer, I. Rudan, R. Ruizbakiev, H. Sahakyan, A. Sajantila, A. Salas, E.B. Starikovskaya, A. Tarekegn, D. Toncheva, S. Turdikulova, I. Uktveryte, O. Utevska, R. Vasquez, M. Villena, M. Voevoda, C.A. Winkler, L. Yepiskoposyan, P. Zalloua, T. Zemunik, A. Cooper, C. Capelli, M.G. Thomas, A. Ruiz-Linares, S.A. Tishkoff, L. Singh, K. Thangaraj, R. Villems, D. Comas, R. Sukernik, M. Metspalu, M. Meyer, E.E. Eichler, J. Burger, M. Slatkin, S. Pääbo, J. Kelso, D. Reich, J. Krause, Ancient human genomes suggest three ancestral populations for present-day Europeans. Nature 513(7518), 409-413 (2014).

35. I. Mathieson, I. Lazaridis, N. Rohland, S. Mallick, N. Patterson, S. A. Roodenberg, E. Harney, K. Stewardson, D. Fernandes, M. Novak, K. Sirak, C. Gamba, E.R. Jones, B. Llamas, S. Dryomov, J. Pickrell, J.L. Arsuaga, J. M. Bermúdez de Castro, E. Carbonell, F. Gerritsen, A. Khokhlov, P. Kuznetsov, M. Lozano, H. Meller, O. Mochalov, V. Moiseyev, M.A. Rojo Guerra, J. Roodenberg, J.M. Vergès, J. Krause, A. Cooper, K.W. Alt, D. Brown, D. Anthony, C. Lalueza-Fox, W. Haak, R. Pinhasi, D. Reich, Genome-wide patterns of selection in 230 ancient Eurasians. Nature 528, 499-503 (2015).

36. Gene Ontology Consortium. The gene ontology resource: 20 years and still GOing strong. Nucleic Acids Research 47(D1), D330-D338 (2019).

37. D.W. Huang, B.T. Sherman, R.A. Lempicki, Bioinformatics enrichment tools: paths toward the comprehensive functional analysis of large gene lists. Nucleic Acids Research 37(1), 1-13 (2009).

38. B.T. Sherman, R.A. Lempicki, Systematic and integrative analysis of large gene lists using DAVID bioinformatics resources. Nature protocols 4(1), 44-57 (2009).

39. P.J. Thul, C. Lindskog, The human protein atlas: a spatial map of the human proteome. Protein Science 27(1), 233-244 (2018). 
40. C. Posth, C. Wißing, K. Kitagawa, L. Pagani, L. van Holstein, F. Racimo, K. Wehrberger, N.J. Conard, C.J. Kind, H. Bocherens, J. Krause, Deeply divergent archaic mitochondrial genome provides lower time boundary for African gene flow into Neanderthals. Nat. Comm. 8, 16046 (2017).

41. M. Lipson, I. Ribot, S. Mallick, N. Rohland, I. Olalde, N. Adamski, N. Broomandkhoshbacht, A.M. Lawson, S. López, J. Oppenheimer, K. Stewardson, R. Neba'ane Asombang, H. Bocherens, N. Bradman, B.J. Culleton, E. Cornelissen, I. Crevecoeur, P. de Maret, F.L.M. Fomine, P. Lavachery, C. Mbida Mindzie, R. Orban, E. Sawchuk, P. Semal, M.G. Thomas, W. Van Neer, K.R. Veeramah, D.J. Kennett, N. Patterson, G. Hellenthal, C. Lalueza-Fox, S. MacEachern, M.E. Prendergast, D. Reich, Ancient West African foragers in the context of African population history. Nature 577, 665-670 (2020).

42. N. Gamage et al. Human sulfotransferases and their role in chemical metabolism. Toxicological sciences 90(1), 5-22 (2006).

43. T.P. Dooley, Cloning of the human phenol sulfotransferase gene family: three genes implicated in the metabolism of catecholamines, thyroid hormones and drugs. Chemico-biological interactions 109(1-3), 29-41 (1998).

44. M.A.T. Hildebrandt, O.E. Salavaggione, Y.N. Martin, H.C. Flynn, S. Jalal, E.D. Wieben, R.M. Weinshilboum, Human SULT1A3 pharmacogenetics: gene duplication and functional genomic studies. Biochemical and biophysical research communications, 321(4), 870-878 (2004).

45. M.W.H. Coughtrie, Function and organization of the human cytosolic sulfotransferase (SULT) family. Chemico-Biological Interactions 259, 2-7 (2016).

46. R. Dajani, A. Cleasby, M. Neu, A.J. Wonacott, H. Jhoti, A.M. Hood, S. Modi, A. Hersey, J. Taskinen, R.M. Cooke, G.R. Manchee, M.W.H. Coughtrie, X-ray crystal structure of human dopamine sulfotransferase, SULT1A3: molecular modeling and quantitative structure-activity relationship analysis demonstrate a molecular basis for sulfotransferase substrate specificity. Journal of Biological Chemistry 274(53), 37862-37868 (1999).

47. K.D. Alex, E.A. Pehek, Pharmacologic mechanisms of serotonergic regulation of dopamine neurotransmission. Pharmacology \& therapeutics 113(2), 296-320 (2007).

48. A.F. Bairam, M.I. Rasool, F.A. Alherz, M.S. Abunnaja, A.A El Daibani, S.A. Gohal, K. Kurogi, Y. Sakakibara, M. Suiko, M.C. Liu, Sulfation of catecholamines and serotonin by SULT1A3 allozymes. Biochemical pharmacology 151, 104-113 (2018).

49. X. Ding, L.S. Kaminsky, Human extrahepatic cytochromes P450: function in xenobiotic metabolism and tissue-selective chemical toxicity in the respiratory and gastrointestinal tracts. Annual Review of Pharmacology and Toxicology 43, 149-73 (2003).

50. E.E. Khrameeva, K. Bozek, L. He, Z. Yan, X. Jiang, Y. Wei, K. Tang, M.K. Gelfand, K. Prüfer, J. Kelso, S. Pääbo, P. Giavalisco, M. Lachmann, P. Khaitovich, Neanderthal ancestry drives evolution of lipid catabolism in contemporary Europeans. Nature Communications 5 (2014).

51. P. Hsieh, M.R. Vollger, V. Dang, D. Porubsky, C. Baker, S. Cantsilieris, K. Hoekzema, A.P. Lewis, K.M. Munson, M. Sorensen, Z.N. Kronenberg, S. Murali, B.J. Nelson, G. Chiatante, F.A.M. Maggiolini, H. Blanché, J.G. Underwood, F. Antonacci, J-F. Deleuze, E.E. Eichler, Adaptive archaic introgression of copy number variants and the discovery of previously unknown human genes. Science 366(6463) (2019).

52. C. Brocker, C. Carpenter, D.W. Nebert, V. Vasiliou, Evolutionary divergence and functions of the human acyl-CoA thioesterase gene (ACOT) family. Human genomics 4(6), 1-10 (2010).

53. M.C. Hunt, A. Rautanen, M.A. Westin, L.T. Svensson, S.E. Alexson, Analysis of the mouse and human acyl-CoA thioesterase (ACOT) gene clusters shows that convergent, functional evolution results in a reduced number of human peroxisomal ACOTs 1. The FASEB journal 20(11), 1855-1864 (2006).

54. M.P. Franklin, A. Sathyanarayan, D.G. Mashek, Acyl-CoA thioesterase 1 (ACOT1) regulates PPAR $\alpha$ to couple fatty acid flux with oxidative capacity during fasting. Diabetes 66(8), 2112-2123, (2017).

55. W. Davies, D. White, M. Lewis, C. Stringer, Evaluating the transitional mosaic: frameworks of change from Neanderthals to Homo sapiens in eastern Europe. Quat. Sci. Rev. 118, 211-242 (2015).

56. E. Morin, Rethinking the emergence of bone grease procurement. Journal of Anthropological Archaeology 59, 101178 (2020).

57. L.D. Bradford, CYP2D6 allele frequency in European Caucasians, Asians, Africans and their descendants. Pharmacogenomics 3(2), 229-43 (2002).

58. B. Wang, L.P. Yang, X.Z. Zhang, S.Q. Huang, M. Bartlam, S.F. Zhou, New insights into the structural characteristics and functional relevance of the human cytochrome P450 2D6 enzyme. Drug Metabolism Reviews 41(4), 573-643 (2009).

59. X. Wang, J. Li, G. Dong, J. Yue, The endogenous substrates of brain CYP2D. European Journal of Pharmacology 724, 2118 (2014).

60. H.F. Sims, M.E. Lowe, The human colipase gene: isolation, chromosomal location, and tissue-specific expression. Biochemistry 31(31), 7120-5 (1992).

61. N. Miled, S. Canaan, L. Dupuis, A. Roussel, M. Rivière, F. Carrière, A. de Caro, C. Cambillau, R. Verger, Digestive lipases: from three-dimensional structure to physiology. Biochimie 82(11), 973-86 (2000).

62. S.M. Zekavat, S. Ruotsalainen, R.E. Handsaker, M.Alver, J. Bloom, T. Poterba, C. Seed, J. Ernst, M. Chaffin, J. Engreitz, G.M. Peloso, A. Manichaikul, C. Yang, K.A. Ryan, M.Fu, W.C. Johnson, M. Tsai, M. Budoff, R.S. Vasan, L.A. Cupples, J.I. Rotter, S.S. Rich, W. Post, B.D. Mitchell, A. Correa, A. Metspalu, J.G. Wilson, V. Salomaa, M. Kellis, M.J. Daly, B.M. Neale, S. McCarroll, I. Surakka, T. Esko, A. Ganna, S. Ripatti, S. Kathiresan, P. Natarajan, NHLBI TOPMed Lipids Working Group, Deep coverage whole genome sequences and plasma lipoprotein(a) in individuals of European and African ancestries. Nat. Comm. 9, 2606 (2018).

63. C. Geng, Y. Zhang, Y. Gao, W. Tao, H. Zhang, X. Liu, F. Fang, Y. Chang, MST1 regulates hepatic lipid metabolism by inhibiting Sirt1 ubiquitination in mice. Biochemical and Biophysical Research Communications 471(4), 444-449 (2016). 
64. E. Huerta-Sánchez, X. Jin, Asan, Z. Bianba, B.M. Peter, N. Vinckenbosch, Y. Liang, X. Yi, M. He, M. Somel, P. Ni, B. Wang, X. Ou, Huasang, J. Luosang, Z.Xi Ping Cuo, K. Li, G. Gao, Y. Yin, W. Wang, X. Zhang, X. Xu, H. Yang, Y. Li, J. Wang, J. Wang, R. Nielsen, Altitude adaptation in Tibet caused by introgression of Denisovan-like DNA. Nature 512(7513), 194-197 (2014).

65. A.W. Bigham, M.J. Wilson, C.G. Julian, M. Kiyamu, E. Vargas, F. Leon-Velarde, M. Rivera-Chira, C. Rodriquez, V.A. Browne, E. Parra, T.D. Brutsaert, L.G. Moore, M.D. Shriver, Andean and Tibetan patterns of adaptation to high altitude. American Journal of Human Biology 25(2), 190-197 (2013).

66. T.D. Brutsaert, M. Kiyamu, G.E. Revollendo, J.L. Isherwood, F.S. Lee, M. Rivera-Ch, F. Leon-Velarde, S. Ghosh, A.W. Bigham, Association of EGLN1 gene with high aerobic capacity of Peruvian Quechua at high altitude. Proceedings of the National Academy of Sciences 116(48), 24006-24011 (2019).

67. M. Sazzini, G. Schiavo, S. De Fanti, P.L. Martelli, R. Casadio, D. Luiselli, Searching for signatures of cold adaptations in modern and archaic humans: hints from the brown adipose tissue genes. Heredity 113, 259-267 (2014).

68. M.E. Lidell, Brown adipose tissue in human infants. Brown adipose tissue, 107-123 (2018).

69. K. Jaouen, M.P. Richards, A. Le Cabec, F. Welker, W. Rendu, J.J. Hublin, M. Soressi, S. Talamo, Exceptionally high $\delta 15 \mathrm{~N}$ values in collagen single amino acids confirm Neandertals as high-trophic level carnivores. Proceedings of the National Academy of Sciences 116(11), 4928-4933 (2019).

70. K. Shebanits, J.C. Andersson-Assarsson, I. Larsson, L.M. Carlsson, L. Feuk, D. Larhammar, Copy number of pancreatic polypeptide receptor gene NPY4R correlates with body mass index and waist circumference. PloS ONE 13(4), e0194668 (2018).

71. K. Shebanits, S. Vasile, B. Xu, H. Gutiérrez-de-Terán, D. Larhammar, Functional characterization in vitro of twelve naturally occurring variants of the human pancreatic polypeptide receptor NPY4R. Neuropeptides 76, 101933 (2019).

72. I.T. Jolliffe, J. Cadima, Principal component analysis: a review and recent developments. Philosophical Transactions of the Royal Society A: Mathematical, Physical and Engineering Sciences, 374(2065), 20150202 (2016).

73. S. Tsibulnikov, L. Maslov, N. Voronkov, P. Oeltgen, Thyroid hormones and the mechanism of adaptation to cold. Hormones 19, 329-339 (2020).

74. L. Wadley, L. Backwell, F. d'Errico, C. Sievers, Cooked starchy rhizomes in Africa 170 thousand years ago. Science 367, 87-91 (2020).

75. A. Revedin, B. Aranguren, R. Becattini, L. Longo, E. Marconi, M. Mariotti Lippi, N. Skakun, A. Sinitsyn, E. Spiridonova, J. Svoboda, Thirty thousand-year-old evidence of plant food processing. Proc. Natl. Acad. Sci. USA 107(44), 18815-18819 (2010).

76. A.G. Henry, A.S. Brooks, D.R. Piperno, Microfossils in calculus demonstrate consumption of plants and cooked foods in Neanderthal diets (Shanidar III, Iraq; Spy I and II, Belgium). Proceedings of the National Academy of Sciences 108(2), 486491 (2011).

77. S. El Zaatari, F.E. Grine, P.S. Ungar, J.J Hublin, Neandertal versus Modern Human Dietary Responses to Climatic Fluctuations. PLOS ONE 11(4), e0153277 (2016).

78. L. Longo, S. Altieri, G. Birarda, C. Cagnato, V. Graziani, T. Obada, I. Pantyukhina, P. Ricci, N. Skakun, G. Sorrentino, V. Terekhina, L. Vaccari, C. Lubritto, A multidimensional approach to investigate use-related biogenic residues on percussive stone tools. Environmental Archaeology (2021a).

79. L. Longo, N. Skakun, I.E. Pantyukina, V. Terekhina, G. Sorrentino, Aurignacian Ground Stone from Surein I (Crimea): "Trace-ing" the roots of starch-based diet. J. Arch. Sci.: Rep 38, 102999 (2021b)

80. E. Trinkaus, Neandertal limb features and cold adaptation. Aspects of human evolution. London: Taylor and Francis LTD. p, 187-224 (1981).

81. T.W. Holliday, Postcranial evidence of cold adaptation in European Neandertals. American Journal of Physical Anthropology: The Official Publication of the American Association of Physical Anthropologists 104(2), 245-258 (1997).

82. B. Vernot, J.M. Akey, Resurrecting surviving Neandertal lineages from modern human genomes. Science 343, 1017-1021 (2014).

83. S. Sankararaman, S. Mallick, M. Dannemann, K. Prüfer, J. Kelso, S. Pääbo, N. Patterson, D. Reich, The genomic landscape of Neanderthal ancestry in present-day humans. Nature 507(7492), 354-357 (2014).

84. A.W. Briggs, J.M. Good, R.E. Green, J. Krause, T. Maricic, U. Stenzel, Lalueza-Fox, P. Rudan, D. Brajković, Ž. Kućan, I. Gušić, R. Schmitz, V.B. Doronichev, L.V. Golovanova, M. de la Rasilla, J. Fortea, A. Rosas, S. Pääbo, Targeted retrieval and analysis of five Neandertal mtDNA genomes. Science 325(5938), 318-321 (2009).

85. M.V. Dobrovolskaya, A.V. Tiunov, Stable isotope (13C/12C and 15N/14N) evidence for Late Pleistocene hominines' Palaeodiets in Gorny Altai. In Proceedings of the International Symposium Characteristic Features of the Middle to Upper Paleolithic Transition in Eurasia: Development of Culture and Evolution of Homo Genus (July 4-10, 2011, Denisova Cave, Altai). Novosibirsk: Publishing Department of the Institute of Archaeology and Ethnography SB RAS (2011).

86. M.V. Dobrovolskaya, A.V. Tiunov, The Neanderthals of Okladnikov Cave Altai: Environment and Diet Based on Isotopic Analysis. Archaeology, Ethnology and Anthropology of Eurasia 41(1), 78-88 (2013).

87. D.C. Salazar-García, R.C. Power, N. Rudaya, K. Kolobova, S. Markin, A. Krivoshapkin, A.G. Henry, M.P. Richards, B. Viola, Dietary evidence from Central Asian Neanderthals: A combined isotope and plant microremains approach at Chagyrskaya Cave (Altai, Russia). Journal of Human Evolution 156, 102985 (2021).

88. M. Ben-Dor, A. Gopher, R. Barkai, Neandertals' large lower thorax may represent adaptation to high protein diet. American journal of physical anthropology 160(3), 367-378 (2016).

89. M.V. Sorensen, W. Leonard, Neandertal energetics and foraging efficiency, Journ. of Hum. Evol. 40(6), 483-495 (2001). 
90. J.J. Snodgrass, W.R. Leonard, M.L. Robertson, The energetics of encephalisation in early hominids, in J-J.Hublin, M.P. Richards (Hrsg.), The Evolution of Hominin Diets: Integrating Approaches to the Study of Palaeolithic Subsistence, Springer, S. $15-29$ (2009).

91. R.C.Power, D.C.Salazar García, M. Rubini, A. Darlas, K. Harvati, M. Walker, J-J. Hublin, A.G.Henry, Dental calculus indicates widespread plant use within the stable Neanderthal dietary niche. J. Hum. Evol. 119, 27-41 (2018).

92. C. Kaleta, L.F. de Figueiredo, S. Schuster, Against the stream: relevance of gluconeogenesis from fatty acids for natives of the arctic regions. International journal of circumpolar health 71(1), 18436 (2012).

93. P.M. de Castro Cardoso Pereira, A.F. dos Reis Baltazar Vicente, Meat nutritional composition and nutritive role in the human diet. Meat Science 93, 586-592 (2013).

94. S. Dhital, A. Hui-Mei Lin, B.R. Hamaker, M.J. Gidley, A. Muniandy, Mammalian Mucosal a-Glucosidases Coordinate with a-Amylase in the Initial Starch Hydrolysis Stage to Have a Role in Starch Digestion beyond Glucogenesis. PLoS ONE 8, e62546 (2013).

95. L. Cordain, J.B. Miller, S.B. Eaton, N. Mann, S.H. Holt, J.D. Speth, Plant-animal subsistence ratios and macronutrient energy estimations in worldwide hunter-gatherer diets. The American journal of clinical nutrition 71(3), 682-692 (2000).

96. Y. Melamed, M.E. Kislev, E. Geffen, S. Lev-Yadun, N. Goren-Inbar, The plant component of an Acheulian diet at Gesher Benot Ya'aqov, Israel. Proceedings of the National Academy of Sciences 113(51), 14674-14679 (2016).

97. J. Zilhão, D. E. Angelucci, M. Araújo Igreja, L. J. Arnold, E. Badal, P. Callapez, J. L. Cardoso, F. d'Errico, J. Daura, M. Demuro, M. Deschamps, C. Dupont, S. Gabriel, D. L. Hoffmann, P. Legoinha, H. Matias, A. M. Monge Soares, M. Nabais, P. Portela, A. Queffelec, F. Rodrigues, P. Souto, Last Interglacial Iberian Neandertals as fisher-hunter-gatherers. Science 367(6485) (2020).

98. M. Kuhlwilm, I. Gronau, M.J. Hubisz, C. de Filippo, J. Prado-Martinez, M. Kircher, Q. Fu, H.A. Burbano, C. Lalueza-Fox, M. de la Rasilla, A. Rosas, P. Rudan, D. Brajkovic, Ž. Kucan, I. Gušic, T. Marques-Bonet, A.M. Andrés, B. Viola, S. Pääbo, M. Meyer, A. Siepel, S. Castellano, Ancient gene flow from early modern humans into eastern Neandertals. Nature 530, 429433 (2016).

99. P.S. Ungar, M. Sponheimer, Hominin diets. A companion to paleoanthropology, 165-182 (2013)

100. L.A. Frassetto, M. Schloetter, M. Mietus-Synder, R.C. Morris, A. Sebastian, Metabolic and physiologic improvements from consuming a paleolithic, hunter-gatherer type diet. European journal of clinical nutrition 63(8), 947-955 (2009).

101. C. Larbey, S.M. Mentzer, B. Ligouis, S. Wurz, M.K. Jones, Cooked starchy food in hearths ca. 120 kya and 65 kya (MIS 5e and MIS 4) from Klasies River Cave, South Africa. J. Hum. Evol. 131, 210-227 (2019).

102. H. Li, B. Handsaker, A. Wysoker, T. Fennell, J. Ruan, N. Homer, G. Marth, G. Abecasis, R. Durbin, 1000 Genome Project Data Processing Subgroup, The sequence alignment/map format and SAMtools. Bioinformatics, 25(16), 2078-2079 (2009).

103. Y.C. Chen, T. Liu, C.H. Yu, T.Y. Chiang, C.C. Hwang, Effects of GC bias in next-generation-sequencing data on de novo genome assembly. PloS ONE 8(4), e62856 (2013).

104. F. Ramírez, D.P. Ryan, B. Grüning, V. Bhardwaj, F. Kilpert, A.S. Richter, S. Heyne, F. Dündar, T. Manke, deepTools2: a next generation web server for deep-sequencing data analysis. Nucleic Acids Research 44(W1), W160-W165 (2016).

105. Y. Benjamini, T.P. Speed, Summarizing and correcting the GC content bias in high-throughput sequencing. Nucleic acids research $40(10)$, e 72-e72 (2012).

106. ENCODE Project Consortium. An integrated encyclopedia of DNA elements in the human genome. Nature 489(7414), 57 (2012).

107. B.S. Pedersen, A.R. Quinlan, Mosdepth: quick coverage calculation for genomes and exomes. Bioinformatics 34(5), 867-868 (2018).

108. D.R. Zerbino, P. Achuthan, W. Akanni, M. R. Amode, D. Barrell, J. Bhai, K. Billis, C. Cummins, A. Gall, C. García Girón, L. Gil, L. Gordon, L. Haggerty, E. Haskell, T. Hourlier, O.G. Izuogu, S.H. Janacek, T. Juettemann, J. Kiang To, M.R. Laird, I. Lavidas, Z. Liu, J.E. Loveland, T. Maurel, W. McLaren, B. Moore, J. Mudge, D.N. Murphy, V. Newman, M. Nuhn, D. Ogeh, C. Kee Ong, A. Parker, M. Patricio, H. Singh Riat, H. Schuilenburg, D. Sheppard, H. Sparrow, K. Taylor, A. Thormann, A. Vullo, B. Walts, A. Zadissa, A. Frankish, S.E. Hunt, M. Kostadima, N. Langridge, F.J. Martin, M. Muffato, E. Perry, M. Ruffier, D.M. Staines, S.J. Trevanion, B.L. Aken, F. Cunningham, A. Yates, P. Flicek, Ensembl 2018. Nucleic Acids Research 46(D1), D754-D761 (2018).

109. V. Fabre, S. Condemi, A. Degioanni, Genetic Evidence of Geographical Groups among Neanderthals. PloS ONE 4(4), e5151 (2009).

110. L. Dalén, L. Orlando, B. Shapiro, M. Brandström-Durling, R. Quam, M. T.P. Gilbert, J.C.D. Fernández-Lomana, E. Willerslev, J.L. Arsuaga, A. Götherström, Partial Genetic Turnover in Neandertals: Continuity in the East and Population Replacement in the West, Molecular Biology and Evolution 29(8), 1893-1897 (2012).

Acknowledgments: We thank Alissa Mittnik (Johannes Krause lab) for sharing her estimate of contamination of the Motala 12 nuclear genome.

Funding: This work has been partially supported by:

- ANR grant STARCH4SAPIENS - grant ANR-20-CE03-0002 (AC, SC, LL); 
- LabEx CALSIMLAB grant ANR-11-LABX-0037-01 - constituting part of the "Investissements d'Avenir" program grant ANR-11-IDEX-0004-02 (AC, RV);

- SUG grant M4081669.090 (NTU, Singapore) (LL);

- PHC Merlion, 2018, Singapore-France bilateral agreement (NTU, Singapore) (LL, SC).

\section{Author contributions:}

Conceptualization: AC, LL, SC

Methodology: AC, RV

Investigation: AC, LL, SC, RV, LP

Visualization: AC, RV, LP

Funding acquisition: AC, LL, SC

Supervision: AC

Writing - original draft: AC, LL

Writing - review \& editing: AC, LL, SC

Writing - SOM: AC, LL, SC, RV, LP

All the authors discussed the results and agree on the final version.

Competing interests: Authors declare that they have no competing interests.

Data and materials availability: All data are available in the main text or the supplementary materials. 


\title{
Supplementary Materials
}

\section{Dietary adaptation in Neandertal, Denisovan and Sapiens revealed by gene copy number variation}

\author{
R. Vicedomini, L. Polit, S. Condemi, L. Longo, A. Carbone
}

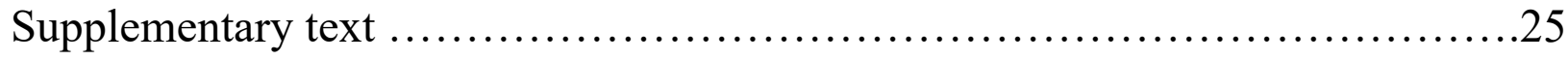

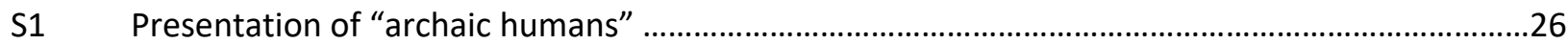

S1.1 -------- The Hs peopling of Europe seen from paleoanthropological and genomic analyses........27

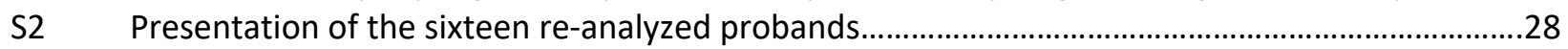

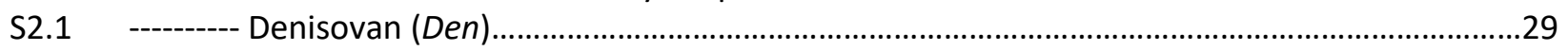

S2.2 - -

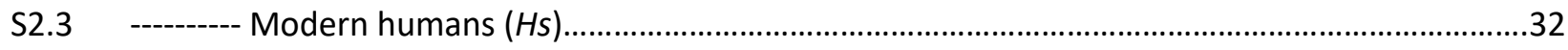

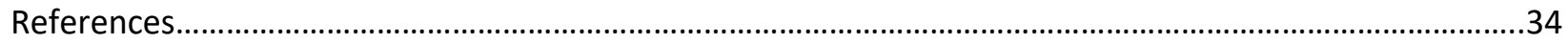

Supplementary tables...................................................

Table S1 - Downloading information for the 16 ancient human genomes.................................................40

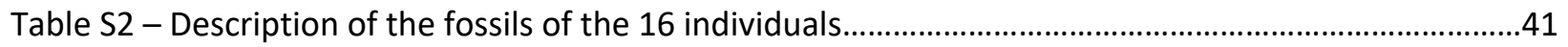

Table S3 - Gene Ontology terms associated with the 11 genes presenting a differential CNV..................42

Table S4 - List of primary tissues and others where the 11 genes are expressed...................................... 45

Table S5 - Estimated haploid copy number for the 11 genes related to digestion.................................... 46 
bioRxiv preprint doi: https://doi.org/10.1101/2021.10.30.466563; this version posted November 2, 2021. The copyright holder for this preprint (which was not certified by peer review) is the author/funder, who has granted bioRxiv a license to display the preprint in perpetuity. It is made available under aCC-BY-NC-ND 4.0 International license.

\section{Supplementary Text}




\section{S1. Presentation of "archaic humans" (SC, LL)}

Neandertals $(\boldsymbol{H n})$ are a human hunter-gatherer fossil population that lived in Eurasia between 300 kya and $40 \mathrm{k}$ ybp. They were totally replaced throughout their territory by us, Homo sapiens. Paleoanthropologists have shown that the evolution of this fossil population could be originated from Homo heidelbergensis in Europe, back at least from $450 \mathrm{k}$ ybp, through the identification and progressive accumulation over time of typical $H n$ morphological features (111).

In Africa Homo heidelbergensis gave rise to Homo sapiens $(H s)$ whose oldest representatives, from fossil remains, are identified around $300 \mathrm{Ka}$ (112). Thus, while $H n$ was differentiating in Europe, $H s$ was differentiating in Africa. These data are consistent with the genetic ones (113). By analysing the genomes of $H n$ and of modern humans $(H s)$ it was estimated that the two ancestral populations separated between 220000 and 470000 years ago (114). This splitting time is highly relevant for the emergence of the AMY1 A/B/C gene cluster (15) and it is relevant for the reasoning presented in this paper. According to some studies, this timeframe would seem to match that of the extinct species Homo heidelbergensis, which has been found in Africa, Europe, and possibly Asia (115). The fact that only present-day Europeans and Asians possess this $H n$ genetic capital indicates that interbreeding must have taken place just after the first humans left Africa to conquer Eurasia, which the researchers estimate to be approximately 100,000 years ago $(116,117)$. This hybridation has been since confirmed by several analyses (the last being 31 ), who succeeded in sequencing the genomes of five $\mathrm{Hn}$, including four late $\mathrm{Hn}$ from Western Europe - one from France, two from Belgium and one from Croatia - and an older one from the Russian Caucasus. They also found that the $\mathrm{Hn}$ genes of present-day Europeans are not close to those of late European $\mathrm{Hn}$. Both this genetic distance and the enigmatic absence of $H s$ genes in late $H n$ can then be explained if one's makes and validate - two hypotheses: on the one hand, that interbreeding mainly induced gene flows in the direction of $\mathrm{Hn} \rightarrow \mathrm{Hs}$; on the other hand, that the main hybridization event occurred outside Europe well before the arrival of our $\mathrm{Hs}$ ancestors on this continent $(116,113,114)$.

The European $\mathrm{Hn}$, for which extensive morphometric data are available, underwent four geological glacial eras and thus progressively adapted to colder environments $(10,118)$. It is therefore under particular climatic and environmental conditions, with alternating glacial and interglacial phases, that the evolution of $H n$ took place in Eurasia. The climate had important consequences for their adaptability, density and therefore diversity, as well as for their possibilities of expansion and contact with their neighbouring population (119). The $H n$ populations have experienced few bottlenecks, therefore they have never been large, structured in small interconnected groups (about 20 individuals) that never outnumbered 70,000 individuals at the time of their "golden age" (during the "Eemian" interglacial at MIS 5, around 120k ybp) (120). The small size of the population has to be correlated with the partial geographic isolation of $\mathrm{Hn}$ caused by European climatic fluctuations during Pleistocene.

It was around this time (circa $100 \mathrm{k}$ ybp) that the European $\mathrm{Hn}$, well identified by singular morphological features, spread eastwards carrying the same lithic assemblages and technology as far east as the Altai mountains (121) where they encountered the Denisovan (Den). Genetic data has also pointed out low genetic diversity in $H n$, with a demographic depression peak in the Altai, where a very consanguineous individual has been found (27), and a genetic continuity across Europe from 120k ybp until the disappearance of the population around 40k ybp (122). This low variability is also visible in the morphology of the $H n$, which remained the same during the last 100k of their existence throughout their broad territory from the Atlantic to the Altai (111; see SOM p.15 in 121).

\section{The expansion of $\mathrm{Hs}$ and the demise of $\mathrm{Hn}$}

After the great dispersion of Homo sapiens (Hs) from Africa into Eurasia about 60,000 years ago (1), the other archaic humans (EAHs), notably the Neandertal $(H n)$ and Denisovan (Den), who populated this 
geographical region, disappeared. The reasons for the success of $H s$ are debated among specialists. The most commonly accepted hypothesis is that EAHs would have competed with $H_{s}$ for food resources during the climatic changes that affected Eurasia $(123,111)$.

The replacement of EAHs, Neandertals in particular, would have been favoured by $H s^{\prime}$ greater technical skills (124), their greater cognitive abilities (124-128) and lower social capacities and network (124, 129130).

However, all these hypotheses have been challenged $(131,132)$ as also those suggesting that the disappearance of EAHs was brought about by violent confrontations between the two populations (133) and by the exposure to new infectious agents $(134,135)$.

The great deal of attention paid to behaviourally and culturally driven reasoning somehow overwhealmed the reasoning on the biological complexity of physiological adaptation $(136,137)$ and comparatively little attention was paid to the metabobolic and physiological processes ruling the bioenergetic requirements ( 14 , 138-140), the role of microbiomes $(141,142)$ and how to transform different foods into nutrients $(143$, 144). Our analysis add fresh data to the genomic architecture across EAHs suggesting a selective pressure on Neandertal, and possibly on Den, towards lipid-rich food to respond to the cold climatic regimes at the boreal latitudes. Conversely, our results support an adaptation to a diet rich in glycemic carbohydrates for $H s$, evidenced by the old duplication of AMY1 A/B/C gene cluster (15).

For our CNV analysis, $8 \mathrm{Hn}$ genomes are available : 2 from the from Asia (in Altai: Altai Neandertal D5 and Chagyrskaya 8) and 6 from Europe (in Russia: Mezmaiskaya 1,Mezmaiskaya 2; in Croatia (Vindija 33.19) and in Belgium (Spy 94a, Les Cottés Z4 1514, Goyet Q56.1).

Denisovan, Den, on the other hand, are also an extinct human population but their "discovery" in 2010 is mainly due to mitochondrial (mt) and nuclear (n) DNA studies $(145,117,146,26)$ extracted from the collagen of bones so fragmentary that they did not allow paleoanthropologists to identify their morphological and anatomical characteristics. Den are considered an Asian sister group of $H n$ that have evolved in Asia from Homo heidelbergensis after the expansion from Africa and the split with the African ancestors. This African origin has been confirmed and reinforced by genetic studies (from 2010 up today), that have also contributed to date the time of divergence between the African lineage, that will evolve into $H s$, and the Eurasians' one that will give rise to $H n$ in Europe and to Den in Asia. The analysis of the nuclear genome suggests a recent common ancestor between European Hn (notably with Vindija, Vi 33-19) and Den dating between 440 to $390 \mathrm{ka}$ ago (30) and thus, situated the Den as a sister group to $H n(25,30,147)$ and $H s$.

The exact geographic repartition of Den is not yet clear but available data supports that the Altai is the western edge of their territory. Den, originally known only from the Denisova cave in the Siberian Altai, has been recognized even in the incomplete hemi-mandible from Baishiya cave (Tibet), on the basis of proteomic study (148) and from DNA extracted from the sediments (149), providing evidence for their occupation of the cave perhaps until $45 \mathrm{ka}$, when early dispersal of $H s$ was already roaming into Asia. Probably, Den occupied a large part of continental and southern regions of Asia (150-154). Indeed, it is in modern Asian populations that the highest percentage of Den genes are found $(155,156)$. Hn and Den have interacted in the Altai area and they occupied successively and perhaps even together Denisova Cave, as witnessed by the Den D11 individual (118.1-79.3k ybp) that had a Den father and an Hn mother $(26,157)$. The D3 and D11 genomes are available for our CNV analysis.

\section{S1.1 The $H s$ peopling of Europe seen from paleoanthropological and genomic analyses}

From archeological, paleoanthropological and genetic studies the European $H s$ peopling show that the ancestry of modern Europeans is quite complex (158). In western Eurasia five dispersals of $H s$ arrival can be identified: 
1) An "Aurignacian dispersal" of $H s$. This arrival is supported by the presence in Eastern and Central Europe of archeological evidence for "Aurignacian flaked industries " resembling those of the Levant, e.g. Ksar Akil, Lebanon, dating about 43k ybp (159). These cultural assemblages, that lasted in western Europe until around $31 \mathrm{k}$ ybp are always associated to $H s$, although at the time of modern humans' arrival $H n$ was still present in Europe (160) making it possible that hybridation have occurred (161).

Although for this early phase of dispersal no genomes are available that belong to it with certainty, in this study we analyzed the Peștera Muierii genome. Other genomes from early $H_{s}$ individuals like Kostenki 14 , dating to $38 \mathrm{k} \mathrm{ybp}(162,163)$, Bacho Kiro, dating 45-58k ybp (161) and Zlatý kůn̆, 45-43k ybp (164) could not be included in our analysis due to genome sequencing characteristics not allowing for CNV analysis (see Methods). For this earliest dispersal we analyzed the Ust-Ishim genome ( $>45 \mathrm{k} \mathrm{ybb})$.

2) $H s$ belonging to the Gravettian assemblages. The Gravettian population seems to have formed a homogeneous biological group despite their chronological and geographical extension that covers all Europe over about 10.000 years. The oldest Gravettian occurrences are dating from around $31 \mathrm{k}$ ybp, when $H n$ had already disappeared, until 23k ybp, hence Peștera Muierii 1 and Mal'ta child genomes fall in this group. These fossil populations of hunter-gatherers developed a meta-culture famous for its flourishing art, as well as some emblematic archaeological sites including the Cro-Magnon shelter discovered in 1868 (Dordogne, France) that gave the name with which modern humans are aknowledged.

All the genomes available from this span time (notably Sungir, Kostenki I, Dolni Vestonice, Pavlov, KremsWachtberg) do not have the genome sequencing characteristics allowing for CNV analysis (see Methods).

3) A new arrival of an unidentified $H s$ population of hunter-gatherers around $14 \mathrm{k}$ ybp, probably coming from Anatolia $(165,166)$. This new arrival expanded in Europe during the last Ice Age $H s$ experienced an important demographic bottleneck. Therefore, there is genetic evidence for discontinuities in the European peopling before and after last glacial maximum. For this span time no available $H s$ genomes are worth to match the criteria set for our CNV analysis.

4) Anatolian $H s$ farmers, who spread into Europe about 8,500 years ago, via the Mediterranean coast and the Danube valley (34). In our study, we analyzed the CNV of genomes from late Mesolithic $H s$, namely Loschbour (Belgium) and Motala 12 (Sweeden) and from an early farmer from Stuttgart, all living in Europe after the great bottleneck that followed the last glacial event.

5) A nomad population from the steppes of southern Russia, who migrated to Europe and East and South Asia about 5,000 years ago $(167,35)$ which is beyond the scope of the present analysis.

\section{S2 Presentation of the sixteen re-analyzed probands}

In recent years, the availability of good quality nuclear DNA from various human fossils has increased the potential of reconstructing the hominins phylogeny and their interbreeding (168). Also, the availability of hundreds of thousands of complete human genomes from different modern populations allows the reconstruction of maps of single nucleotide polymorphisms and structural variants. Among all the ancient DNA genome sequence data on $\mathrm{Hn}$, Den available to date for our unsupervised analysis, we have selected only those with high-quality genomes (see Methods) namely two Den (D3 and D11) and eight Hn (Altai Neandertal D5, Chagyrskaya 8, Mezmaiskaya 1, Spy 94a, Vindija 33.19, Mezmaiskaya 2, Les Cottés Z4 1514, Goyet Q56.1). These probands are representative of the two archaic human (Hn and Den) that spanned over 50,000 years of the Late Pleistocene and approximately 8,000 km across Eurasia. We also analysed three early $H s$ genomes (Ust'Ishim, Peștera Muierii 1, Mal'ta), two late hunter-gatherers and one early farmer from Europe $H s$ genomes (Loschbour, Motala 12, Stuttgart). In all, 16 genomes were selected for the CNV study (Table S1). 


\section{$\underline{\text { S2.1 Denisovan (Den) }}$}

\section{Den D3 (Denisova cave, Altai Mountain, Central Siberia)}

Den D3 ("pinky"), is a distal phalanx of the fifth finger belonging to an adolescent female individual. This is the first fossil attributed to a new fossil population on genetic ground $(145,117,25,26)$. It was unearthed in layer 11.2 square D2 of the East Gallery at Denisova cave (51.40N, 84.68E) during 2008 field season. It has recently been dated to $69-48 \mathrm{k}$ ybp from optical dating of the associated sediments and to 76.2-51.6 kybp using a Bayesian modelling approach that combines chronometric (radiocarbon, uranium-series and optical ages), stratigraphic and genetic information to estimate ages for the hominin fossils at the site (169). Den D3 lived approximately at the same time as Hn Chagyrskaya 8 (28) or slightly before, thus sharing similar environmental conditions.

\section{Den D11 (Denisova cave, Altai Mountain, Central Siberia)}

The identification of Den D11, named "Denny", was made using a new method, ZooMS (170). This small bone fragment of a few centimetres from a long bone belongs to a girl, about 13 years old. Mitochondrial DNA analysis identified Neandertal-type mtDNA, but the nuclear DNA analysis (26) reveals that about $40 \%$ of the DNA fragments from Denny (Den D11) matches Neanderthal DNA whilst the remaining $40 \%$ matches with Den DNA. With equal amounts of Den and Neandertal DNA, Den D11 appears to have had a parent in each group, or Denny's parents belonged to a population of Denisova-Neandertal hybrids. To distinguish between these two scenarios, the researchers estimated the heterozygosity of the Den D11 genome and showed that the proportion of heterozygous sites (i.e. sites with one Neandertal and one Denisova allele) was consistent with her having inherited one set of chromosomes from a Neandertal and the other from a Denisova parents.

Further examination of the genome suggests that her father also had $H n$ ancestry, probably several hundred generations back (169). Also, the Hn mother's genome is closer to that of a Hn found in Vindija in Croatia (Vindija 33-19, see below) than to that from $H n$ population found in the same cave in Siberia (28).

\section{$\underline{\text { S2.2 Neandertals }(H n)}$}

Altai Neandertal, also known as D5 (Denisova cave, Altai Mountain, Central Siberia)

Denisova is the name of a cave which is located at a height of $700 \mathrm{~m}$ asl dominating a green valley crossed by the river Sibiryachikha. The cave is located at the foot of the Altai Mountains in Siberia, near the border between Russia, Mongolia and Kazakhstan. This is not the only cave or prehistoric site in the region as several $\mathrm{Hn}$ skeletal remains have been retrieved in the nearby Okladnikov cave and at Chagyrskaya cave, about $100 \mathrm{~km}$ away (28).

The Altai Hn occupied Denisova cave roughly $110 \mathrm{ka}$ ago $(169,171)$. The Altai Neandertal is represented by a proximal pedal phalanx of a female that furnished a 52-fold genome coverage (27). Several very incomplete fossils from layers 12.3 and 11.4 have also been assigned to $H n$ based on their mitochondrial (170) and nuclear DNA $(27,98)$. Additional evidence for the presence of $H n$ in the cave comes from analyses of sedimentary DNA from at least 2 layers (11 and 14), which indicate several episodes of $H n$ occupation (157).

\section{Chagyrskaya 8 (Chagyrskaya cave, Altai Mountains, Central Siberia)}


Chagyrskaya is a karst cave discovered in 2007 and it is located in southern Western Siberia, near the Charysh River in the foothills of the Altai Mountains. Since 2008, $74 \mathrm{Hn}$ remains, along with fauna and a rich lithic industry, have been unearthed, providing a large and mostly well-preserved collection of morphologically diagnostic $\mathrm{Hn}$ remains from the Altai mountains. The faunal and pollen remains suggest a milder climate in the Altai foothills that was likely a refugium for $\mathrm{Hn}$ populations during the late Pleistocene (172-176, 87).

Chagyrskaya 8 is a distal manual phalanx from a $H n$ individual whose genomes have been sequenced to 27-fold genomic coverage (28).

Although the age of Chagyrskaya 8 is constrained by a DNA-based estimate of $\sim 80$ ybp (28) and an optical age for the associated deposits of 59-49 ybp, Chagyrskaya 8 may have lived at around the same time than Den D3 or up to several millennia later. The genome from Chagyrskaya 8 shows that this $H n$ is related to $H n$ from western Eurasia (notably with Vindija 33-19) more than to the Altai $H n$ who lived earlier in Denisova Cave $(28,27,30,31)$. This suggests that distinct groups of Neandertals repeatedly migrated between Western Eurasia and Siberia $(98,121)$. Also, this is consistent with the fact that Siberian Hn lived in relatively isolated populations of less than 60 individuals on the Eastern edge of the $H n$ territory.

The long-distance movements from western Europe to Altai of $\mathrm{Hn}$ is further confirmed by the studies of lithic assemblages - more than 90,000 pieces - resembling to the so-called "Micoquian-like assemblages" observed in Central and Eastern Europe (121). These connections are also supported by a recent study on $H n$ blood system (111). These data make it possible to explain the great homogeneity that is observed in the anatomical characteristics of the $H n$, which is found throughout their territory from west to east and over the course of time from the earliest to the most recent.

\section{Mezmaiskaya 1, Mezmaiskaya 2 (Mezmaiskaya cave, Krasnodar region, Caucasus, Southern Russia)}

Mezmaiskaya Cave is located near the right bank of the Sukhoi Kurdzhips river, in the north-western foothills of the North Caucasus, southern Russia. Among several Hn remains retrieved in the cave, the genome extracted from a rib of a still breast-feeding neonate (Mez 1, who died about 2 weeks after birth) dating back to $\sim 70 \mathrm{k}$ ybp was the second $H n$ genome sequenced after the Feldhofer, retrieved in the eponym site, in the early 2000s (177).

In 2016, a successful extraction from a skull fragment of another infant (Mez 2, 1-2 years old, so putatively still breast-feeding) dated to $44,6-42,96 \mathrm{k}$ ybp, revealed an optimal collagen preservation that permitted to sequence the genome (31).

The still ongoing excavation, by yielding human skeletal remains associated with middle Paleolithic assemblages of local facies called "Micoquian tradition" (178), has revealed the key role played by the Caucasus corridor not only for $\mathrm{Hn}$ but also as one of the gateways for $H s$ into the boreal latitudes.

\section{Vindija 33.19 (Vindija cave, Northern Croatia, Southern Central Europe)}

The Vindija Cave, in the Dinarides Alps, discovered in 1974, is a highly recognized site for the richness in human skeletal remains of both $H n$ and a few $H s$. Three fragmentary bones of $H n$ were analyzed for the first draft sequence of the Neanderthal genome project (110). In our analysis we consider Vindija 33.19 , one of the five $H n$ osseous remains that were recently genotyped $(30,31)$. It belongs to a $H n$ female that lived 48-65k ybp (179) and furnished a 30-fold genome (30).

The comparison with the previous $H n$ genomes (116) allowed inferences on the similarity the Neandertal population from Vindija with late $H n$ from western Europe and from the Gibraltar area (122). However, the recently obtained Vi 33-19 genome was compared with those of Chagyrskaya 8 and of the other $H n$ individuals retrieved in that cave, allowing inferences on the western origins of these Altai $\mathrm{Hn}$, even considering the technological skills observed in the lithic assemblages $(121,28,87)$.

Several individuals from Croatian site have been also deeply investigated for dental microwear texture analysis and the results suggest that some individuals among the Vindija $H n$ where consuming soft food 
like meat at high level (180) and this data are fully in agreement with our results and with the isotopic analysis (181) although anisotropy on teeth wear may suggest some raw fibrous plant food.

Spy 94a (cave in the Namur province, Belgium)

The site of Spy is well known since the end of 19th century and yielded $H n$ several individuals, highly fragmented. The first two skeletons were discovered in 1886 in Jemeppe-sur-Sambre, province of Namur, Belgium $(182,183)$ and represent the second official discovery of Neandertal fossils ever reported, thirty years after the one in the Neander Valley in Germany (Feldhofer). Since 2010, the re-examination of all the human remains have permitted to identify at least 6 individuals, one juvenile and five adults.

The genome considered in our study, was obtained from Spy-94a upper right molar $\left(\mathrm{M}_{3}\right)$ from the male individual Spy I and it is associated with a maxillary fragment dated to 39,150-37,880 ybp (according to redating study by 184). The tooth was bearing dental calculus in which starch grains have been retrieved allowing the inference that Spy I individual was including some plant food in its diet (76), which is in accordance with the tooth wear-traces observed by 185 . Also, tooth wear from Spy I resemble those observed in different individuals from Vindija (but not from Vi 33.19, the specimen in our analysis), Krapina, Hortus and from Kulna 1 (these three latter individuals are not genotyped), and the wear is interpreted as coherent with some plant food consumption (186). Our data on Spy I/94a by showing the duplication of the AMY1 A/B/C gene cluster, lend support to the just mentioned data. However, at present, it is not possible to directly compare our genes CNV trends with the data from other $H n /$ Early $H s$ specimen yielding starch entrapped in dental calculus as reported in recent reviews $(91,186)$.

Furthermore, other studies caution about the attribution of plant remains retrieved in dental calculus to the exclusive connection with food consumption (187) and bring about insights on the use of teeth as the "third hand" therefore starch, fibres, tissues residues entrapped in the calculus might also be referred to alternative plants processing (e.g. for technological processing) or for medical purposes $(188,189)$.

\section{Goyet Q56-1 ("third cavern” of Goyet cave, Belgium, Central Europe)}

The so-called "third cavern" cave, excavated during the 19th century and then re-opened in the 1990s, belongs to a large karstic complex in the Mosan basin, Belgium. It yielded almost 100 human skeletal remains and a rich Middle and Upper Paleolithic industries difficult to disentangle due to the methodology applied by Dupont, one of the pioneers of the studies in Prehistory. Among the many remains attributed to $\mathrm{Hn}$, for the CNV analysis we consider the Goyet Q56-1 genome, obtained from the fragment of the right femur (31) and dated to $40.5-45.5 \mathrm{k}$ ybp. The isotopic analysis has been carried out on several fragments of other $H n$ genotyped fragments (Q119-2, Q305-4, Q305-7, according to mtDNA) and the data closely resemble those from other Western and Central Europe hominins like Feldhofer, El Sidron and Vindija (190). The modest genetic variation shown by these genomes is supportive of the low genetic variability typically explained by the limited number of individuals of late $H n$ clades. It has to be mentioned that dental calculus analysis was carried out on Goyet VI Hn individual highlighting that this individual was adding some plant food on his prevailing carnivore diet (Power et al. 2018). According to our data Goyet Q56-1 together with Spy I/94a and Les Cottés Z4-1514 (see below) - shows the duplication of the AMY1 A/B/C gene cluster lending credence to the digestion of dietary carbohydrates for these individuals. However, carbon isotopic data suggest that other $H n$ individuals living at Goyet cave were heavily relying on mammoth, as it occurred for Spy and Scladina Neandertals (191), which is also a dietary condition supported by our data (high duplication of the genes involved in lipid and protein metabolism).

\section{Les Cottés Z4-1514 (Les Cottés cave, New Aquitaine, France, Western Europe)}


The Cottés cave or Cottets cave is located in Saint-Pierre-de-Maillé, in France. The first excavations and discoveries of Mousterian and Aurignacian occupation levels date back to 1880. Since 2006, new excavations have been carried out, as this cave has the particularity of presenting a continuous archaeological sequence from the end of the Middle Paleolithic to the beginning of the Upper Paleolithic, thus including the Mousterian, the Chatelperronian and the first phases of the Aurignacian. Les Cottés Z41514 , a $H n$ tooth dated to 43,740-42,720 ybp, has been recently genotyped (31) allowing the CNV analysis. As for the two mentioned Belgian Hn individuals, even for Le Cottés Z4-1514 it would be possible to suggest the access to a more mixed diet.

\section{$\underline{\text { S 2.3 Homo sapiens }(H s)}$}

In the frame of this article, we analysed the CNV of an Early $H s$ Palaeolithic hunter-gatherer from Europe, Peştera de Muierii, and two from Asia, Ust'Ishim (north-western Siberia), at present the oldest $H s$ at the boreal latitudes who lived prior to the split between Western and Eastern Eurasian, and the Mal'ta child, that lived in eastern Siberia around 24k ybp.

\section{$\underline{\text { A- Hs Palaeolithic hunter-gatherers }}$}

\section{Peștera Muierii 1 ("Women's cave", Romania, Eastern Europe)}

Peștera Muierii, or the "Women's Cave", opens in a complex karst system in the Carpathian Mountains. The cave yielded numerous cave bear remains as well as a $H_{s}$ human skull.

Together with the human remains found in 1952 - a skull and some post-cranial remains (Peștera Muierii 1 or PM1) a temporal bone (Peștera Muierii 2) that cannot be articulated with the skull, and an isolated fibular diaphysis (Peștera Muierii 3) - lithic artifacts attributed to both the Mousterian technology (usually referred to Neandertals) and to the Aurignacian (associated to early modern humans) were retrieved. The $H s$ remains are dated to about $34 \mathrm{ybp}$ (192), thus, they are somewhat younger than those from the nearby cave of Peștera cu Oase, dated to about 40k ybp (193).

The PM1 skull displays modern human features, including a high forehead, a small maxilla and small eyebrow arches. The large cranial vault and intact facial bones indicate a woman with 'robust features'.

The mitogenome of the skull (192) obtained from two of its teeth suggest that the female from Peștera Muierii was part of the first population of $H s$ after its expansion into Eurasia.

The genome was recently analysed (32) and shows some level of admixture $(\sim 3.1 \%)$ and also a quite high level of genetic diversity, a common trait within the earliest European. The human remains of Peștera Muierii represent a group that was a side branch to the ancestor of modern-day Europeans that underwent a great bottleneck during and after the most recent Ice Age.

\section{Ust'-Ishim (cave on the bank of the Irtysh river, Central Asia, Northern Siberia)}

Ust'-Ishim Man is the name given to the fossil of a $H s$ femur, fortuitously discovered in 2008 on the bank of the Irtysh River by a Russian sculptor near Ust'-Ishim, in the Omsk province of north-western Siberia. This fossil is notable for the preservation of its DNA, which allowed the complete sequencing of its genome, thus becoming the earliest $->45 \mathrm{k}$ ybp - modern human genome sequenced to date $(29,194)$.

The examination genome shows that Ust'-Ishim individual is closely related to the 24 ybp Mal'ta boy (see below) from central Siberia, but also to the much later individual from La Braña (Spain) who lived about 
$8,000 \mathrm{ybp}$. This genetic relationship show that Ust'-Ishim femur belong to a population that predated the separation between western Eurasians (European population) and the eastern Eurasians (Asians populations; 195). Some authors consider Ust'-Ishim likely belonged to a population that predated this split or represented another migration to the Asian continent that would not have left descendants among the present human populations (161). The same authors observed that Neanderthal DNA in Ust'-Ishim appears in longer sequences, indicating that interbreeding between modern humans and $H n$ took place shortly before the life time of this fossil. Calibration of the genetic clock, following the sequencing of the Ust'-Ishim genome, permits to estimate the date of interbreeding between $H s$ and $H n$ at between 52,000 and 58,000 ybp. This age corresponds to the estimated age of the last exit of $H s$ from Africa (159). No hybridisation between Denisovans and Ust'-Ishim has been demonstrated, although Denisovans are thought to have lived at the same time in East Asia as suggested by the DNA retrieved in the sediments of Denisova $(161,157)$.

\section{Mal'ta (open air site, Eastern Siberia, Central Asia, Russia)}

The four-year-old Mal'ta boy lived along the Bolshaya Belaya River near Irkutsk, in central Siberia. This individual is dated 24,300 ybp and belonged to a population settled between the Lake Baikal and the Yanisey River under very rigid climatic conditions with few plants and animals to live on. Nonetheless, they survived in a large community - much larger than the Neandertal's ones - and built hypogeum construction made of mammoths' bones and reindeer antler likely covered with leather, and they were capable of fine carving amulets using the ivory and the antler of that animals (196). The Mal'ta eastern Paleo-Siberian group became genetically isolated from its original population being different from the other populations of the eastern Asia (197). The Mal'ta population is ancestral to Native Americans that received around the $40 \%$ of their ancestry (33) and to the present-day Kets and the Selkups, known as highly carnivores, with whom he shares the high CNV of PGA3/4/5 gene cluster involved in the efficient protein catabolism (198). Our data clearly show that this same adaptation is evident in Neandertal - Spy I/94a and D5 Altai Neandertal - and also Denisovan - D3 and D11. Mal'ta represents the closest link to Motala 12, since the Swedish late hunter-gatherer shows about 22\% of ancient North Eurasian genetic capital (167).

\section{B. Hs from Europe prior the Neolithic: Mesolithic (Motala 12, Loschbour) and early farmer (Stuttgart).}

\section{Motala 12 (necropolis - Kanaljorden, Sweden, Northern Europe)}

Motala 12 is a maxilla belonging to a male individual from the Scandinavian site of Kanaljorden, excavated in the town of Motala between 2009-2013. In this site, attributed to late Mesolithic huntergatherers, several individuals - an infant and 10 adult burials - were retrieved on the shore of a small lake. Motala 12 maxilla was directly dated to 7,212 \pm 109 BP (34, SOM p. 4). The sequenced genome (34, 35) informs that this fossil shares with its cohort large teeth and thick dark hairs and pigmented skin, as it occurred in present days East-Asians (167) and Native Americans. It must be noted that our results finely match with previously available ones for the late northern hunter-gatherers regarding the efficient digestion of dietary carbohydrates and the perception of bitter taste (35).

\section{Loschbour LB 1-3 (rock shelter, Luxembourg, Central Europe)}

The "Loschbour man" (also Loschbur man) is a skeleton discovered in 1935 in rock shelter in Mullerthal (Luxembourg) by Nicolas Thill (34, SOM p. 2). The skeleton now belongs to the collections of the National Museum of Natural History in Luxembourg City. Loschbour man, directly dated in 1998 (AMS) to 7,205 $\pm 50 \mathrm{ybp} \mathrm{(34,SOM} \mathrm{p.} \mathrm{2),} \mathrm{was} \mathrm{a} \mathrm{late} \mathrm{Mesolithic} \mathrm{hunter-gatherer} \mathrm{aged} \mathrm{34-47} \mathrm{years} \mathrm{old,} \mathrm{circa} 1.6 \mathrm{~m}$ tall who 
weighed between 58 and $62 \mathrm{~kg}(199)$. The Loschbourg population was supplanted by new populations more likely used to herd rather than hunting. According to DNA analysis made from a tooth (LB1-3) by (34), Loschbour man was "a light skinned (white) individual" (90\%), with brown or black hair (98\%), and likely blue eyes (56\%). Loschbour's late hunter-gatherer was effective in digesting starchy food, displaying multiple copies of AMY1A/B/C, as the later agro-pastoralist populations (17) that lived in the same area. Also, this individual shows the PAV haplotype for taste receptor TAS2R38 as Motala 12 individual. Loschbour shares with ancient North Siberians the duplication of those genes - namely PGA3/4/5 gene cluster - involved in the amino acid catabolic process, with some genes also involved in the urea cycle and in tyrosine and phenylalanine catabolism (198).

\section{Stuttgart (LBK 1) (Viesenhäuser Hof, Bavaria, Germany)}

A tooth $-\mathrm{M}_{2}$ listed as LBK1- was genotyped within one of the largest studies dedicated to the sequencing of the Holocene ancestral population for present-day Europeans (34). This is an interesting site where both local population and migrant from Anatolia was buried. A female - 25-to 35 years old - affected by primary hyperparathyroidism, lived all her life in the surrounding as the strontium isotope analysis suggests (200) and was buried in this Early Neolithic site as showed by the associated Linear Band Keramik artifacts dating back to 5100 to $4800 \mathrm{ybp}(201)$.

\section{References}

111. S. Condemi, G.-C. Weniger, Eds., Continuity and discontinuity in the peopling of Europe: one hundred fifty years of Neanderthal study. (Springer, Dordrecht [Netherlands], 2011).

112. J-J. Hublin, A. Ben-Ncer, S.E. Bailey, S.E. Freidline, S. Neubauer, M.M. Skinner, I. Bergmann, A. Le Cabec, S. Benazzi, K. Harvati, P. Gunz, New fossils from Jebel Irhoud, Morocco and the pan-African origin of Homo sapiens. Nature 546, 289-292 (2017).

113. F.L. Mendez, G.D. Ponzik, S. Castellano, C.D. Bustamante, The Divergence of Neandertal and Modern Human Y Chromosomes. The American Journal of Human Genetics 98, 728-734 (2016).

114. C. Posth, C. Wißing, K. Kitagawa, L. Pagani, L. van Holstein, F. Racimo, K. Wehrberger, N.J. Conard, C.J. Kind, H. Bocherens, J. Krause, Deeply divergent archaic mitochondrial genome provides lower time boundary for African gene flow into Neanderthals. Nature Communications 8, 16046 (2017).

115. A. Mounier, F. Marchal, S. Condemi, Is Homo heidelbergensis a distinct species? New insight on the Mauer mandible. J. Hum. Evol. 56, 219-246 (2009).

116. R.E. Green, J. Krause, A.W. Briggs, T. Maricic, U. Stenzel, M. Kircher, N. Patterson, H. Li, W. Zhai, M.H-Y. Fritz, N.F. Hansen, E.Y. Durand, A-S. Malaspinas, J.D. Jensen, T. Marques-Bonet, C. Alkan, K. Prüfer, M. Meyer, H.A. Burbano, J.M. Good, R. Schultz, A. Aximu-Petri, A. Butthof, B. Höber, B. Höffner, M. Siegemund, A. Weihmann, C. Nusbaum, E.S. Lander, C. Russ, N. Novod, J. Affourtit, M. Egholm, C. Verna, P. Rudan, D. Brajkovic, Ž. Kucan, I. Gušic, V.B. Doronichev, L.V. Golovanova, C. Lalueza-Fox, M. de la Rasilla, J. Fortea, A. Rosas, R.W. Schmitz, P.L.F. Johnson, E.E. Eichler, D. Falush, E. Birney, J.C. Mullikin, M. Slatkin, R. Nielsen, J. Kelso, M. Lachmann, D. Reich, S. Pääbo, A draft sequence of the Neandertal genome. Science 328(5979), 710-722 (2010).

117. D. Reich, R.E. Green, M. Kircher, J. Krause, N. Patterson, Y.E. Durand, B. Viola, A.W. Briggs, U. Stenzel, P.L.F. Johnson, T. Maricic, J.M. Good, T. Marques-Bonet, C. Alkan, Q. Fu, S. Mallick, H. Li, M. Meyer, E.E. Eichler, M. Stoneking, M. Richards, S. Talamo, M.V. Shunkov, A.P. Derevianko, J-J. Hublin, J. Kelso, M. Slatkin, S. Pääbo, Genetic history of an archaic hominin group from Denisova Cave in Siberia. Nature 468(7327), 1053-1060 (2010).

118. L.C. Aiello, Wheeler, P. Neanderthal thermoregulation and the glacial climate. In: T. van Andel, W. Davies, Eds., Neanderthals and Modern Humans in the European Landscape During the Last Glaciation. McDonald Institute for Archaeological Research, Cambridge, 147-166 (2003).

119. S. Peyrégne, V. Slon, F. Mafessoni, C. de Filippo, M. Hajdinjak, S. Nagel, B. Nickel, E. Essel, A. Le Cabec, K. Wehrberger, N.J. Conard, C.J. Kind, C. Posth, J. Krause, G. Abrams, D. Bonjean, K. Di Modica, M. Toussaint, J. Kelso, M. Meyer, S. Pääbo, K. Prüfer, Nuclear DNA from two early Neandertals reveals 80,000 years of genetic continuity in Europe. Sci. Adv. 5, eaaw5873 (2019)

120. J.P. Bocquet-Appel, A. Degioanni. Neanderthal demographic estimates. Current Anthropology 54(S8), S202-S213 (2013).

121. K.A. Kolobova, R.G. Roberts, V.P. Chabai, Z. Jacobs, M.T. Krajcarz, A.V. Shalagina, A.I. Krivoshapkin, B. Li, T. Uthmeier, S.V. Markin, M.W. Morley, K. O'Gorman, N.A. Rudaya, S. Talamo, B. Viola, A.P. Derevianko, Archaeological evidence for two separate dispersals of Neanderthals into southern Siberia. Proc Natl Acad Sci U S A 117(6), 2879-85 (2020). 
122. L. Bokelmann, M. Hajdinjak, S. Peyrégne, S. Brace, E. Essel, C. de Filippo, I. Glocke, S. Grote, F. Mafessoni, S. Nagel, J. Kelso, K. Prüfer, B. Vernot, I. Barnes, S. Pääbo, M. Meyer, C. Stringer, A genetic analysis of the Gibraltar Neanderthals. Proc Natl Acad Sci U S A 116(31), 15610-5 (2019).

123. N.J. Conard, J. Richter, Eds, Neanderthal Lifeways, Subsistence and Technology - One Hundred Fifty Years of Neanderthal Study [Internet] (Springer Netherlands, Dordrecht, 2011).

124. E. Pearce, C.B. Stringer, R.I.M. Dunbar. New insights into differences in brain organization between Neanderthals and anatomically modern humans. Proc. of the Royal Society B - Biol. Sci. 280(1758), 20130168 (2013).

125. P. Gunz, S. Neubauer, B. Maureille, J.J. Hublin. Brain development after birth differs between Neanderthals and modern humans. Curr. Biol. 20, R921-922 (2010).

126. A. Kyriacou, E. Bruner, Innovation and the Evolution of Human Behavior. Brain Evolution, Innovation, and Endocranial Variations in Fossil Hominids. PaleoAnthropology 130-143 (2011).

127. W. Gilpin, M.W. Feldman, K. Aoki, An ecocultural model predicts Neanderthal extinction through competition with modern humans. Proc. Natl. Acad. Sci. U S A 113, 2134-2139 (2016).

128. T. Kochiyama, N. Ogihara, H.C. Tanabe, O. Kondo, H. Amano, K. Hasegawa, H. Suzuki, M.S. Ponce de León, C.P.E. Zollikofer, M. Bastir, C. Stringer, N. Sadato, T. Akazawa, Reconstructing the Neanderthal brain using computational anatomy. Sci. Rep. 8, 6296 (2018).

129. M.J. Aitken, C.B. Stringer, P. Mellars, Eds, The Origin of modern humans and the impact of chronometric dating: a discussion. Vol. 257 in the series Princeton Legacy Library (Princeton University Press, Princeton, New Jersey, 2014).

130. C.M. Barton, J. Riel-Salvatore, J.M. Anderies, G. Popescu. Modeling Human Ecodynamics and Biocultural Interactions in the Late Pleistocene of Western Eurasia. Hum. Ecol. 39, 705-725 (2011).

131. J. Zilhão, D.E. Angelucci, E. Badal-García, F. d'Errico, F. Daniel, L. Dayet, K. Douka, T.F.G. Higham, M.J. Martínez-Sánchez, R. Montes-Bernárdez, S. Murcia-Mascarós, C. Pérez-Sirvent, C. Roldán-García, M. Vanhaeren, V. Villaverde, R. Wood, J. Zapata, Symbolic use of marine shells and mineral pigments by Iberian Neandertals, Proceedings of the National Academy of Sciences 107(3), 1023-1028 (2010).

132. D.L. Hoffmann, C.D. Standish, A.W.G. Pike, M. García-Diez, P.B. Pettitt, D.E. Angelucci, V. Villaverde, J. Zapata, J.A. Milton, J. Alcolea-González, P. Cantalejo-Duarte, H. Collado, R. de Balbín, M. Lorblanchet, J. Ramos-Muñoz, G-C. Weniger, J. Zilhão, Dates for Neanderthal art and symbolic behaviour are reliable, Nature ecology \& evolution 2(7), 1044-1045 (2018).

133. C.P. Zollikofer, M.S.P. De Leon, B. Vandermeersch, F. Lévêque, Evidence for interpersonal violence in the St. Césaire Neanderthal. Proceedings of the National Academy of Sciences 99(9), 6444-6448 (2002).

134. C.J. Houldcroft, S.J. Underdown. Neanderthal genomics suggests a Pleistocene time frame for the first epidemiologic transition. Am. J. Phys. Anthropol. 160, 379-388 (2016).

135. B. Sørensen. Demography and the extinction of European Neanderthals. J. Anthropol. Archaeol. 30, 17-29.

136. L.C. Aiello, J.C.K. Wells. Energetics and the Evolution of the Genus HOMO. Ann. Rev. Anthropology 31(1), 323-338 (2002).

137. A.T. Da Poian, T. El Bacha, M. Luz. Nutrient Utilization in Humans: Metabolism Pathways. Nature Education 3(9), 11 (2010).

138. D.N. Harris, I. Ruczinski, L.R. Yanek, L.C. Becker, D.M. Becker, H. Guio, T. Cui, F.H. Chilton, R.A. Mathias, T.D. O’Connor, Evolution of Hominin Polyunsaturated Fatty Acid Metabolism: From Africa to the New World. Genome Biology and Evolution 11(5), 1417-1430 (2019).

139. W.R. Leonard, M.L. Robertson, J.J. Snodgrass. What did humans evolve to eat? Metabolic implications of major trends in hominid evolution. In: Human Diet and Nutrition in Biocultural Perspective: Past Meets Present, 5, 14-34 (Berghahn Books, 2010).

140. H. Pontzer 2012. Ecological Energetics in Early Homo. Current Anthropology 53(S6), S346-S358.

141. L. Aiello, Brains and guts in human evolution: The Expensive Tissue Hypothesis, Braz. J. Genet. 20(1) (1997).

142. G.S. Frost, G.E. Walton, J.R. Swann, A. Psichas, A. Costabile, L.P. Johnson, M. Sponheimer, G.R. Gibson, T.G. Barraclough, Impacts of Plant-Based Foods in Ancestral Hominin Diets on the Metabolism and Function of Gut Microbiota In Vitro 5 (3), e00853-14 (2014)

143. K.D. Zink, D.E. Lieberman. Impact of meat and Lower Palaeolithic food processing techniques on chewing in humans. Nature 531, 500-503 (2016).

144. A.R. Smith, R.N. Carmody, J. Dutton, R.W. Wrangham. The significance of cooking for early hominin scavenging. J. Hum. Evol. 84, 62-70 (2015).

145. J. Krause, Q. Fu, J.M. Good, B. Viola, M.V. Shunkov, A.P. Derevianko \& S. Pääbo, The complete mitochondrial DNA genome of an unknown hominin from southern Siberia. Nature 494, 894-897 (2010).

146. S. Sawyer, G. Renaud, B. Viola, J-J. Hublin, M-T. Gansauge, M.V. Shunkov, A.P. Derevianko, K. Prüfer, J. Kelso, S. Pääbo, Nuclear and mitochondrial DNA sequences from two Denisovan individuals. Proc. Natl. Acad. Sci. U S A 112, 15696-15700 (2015).

147. E.A. Bennett, I. Crevecoeur, B. Viola, A.P. Derevianko, M.V. Shunkov, T. Grange, B. Maureille, E-M. Geigl, Morphology of the Denisovan phalanx closer to modern humans than to Neanderthals. Sc. Adv. 5(9), aaw3950 (2019).

148. F. Chen, F. Welker, C-C. Shen, S.E. Bailey, I. Bergmann, S. Davis, H. Xia, H. Wang, R. Fischer, S.E. Freidline, T-L. Yu, M.M. Skinner, S. Stelzer, G. Dong, Q. Fu, G. Dong, J. Wang, D. Zhang, J-J. Hublin, A late Middle Pleistocene Denisovan mandible from the Tibetan Plateau. Nature 569, 409-412 (2019).

149. D. Zhang, H. Xia, F. Chen, B. Li, V. Slon, T. Cheng, R. Yang, Z. Jacobs, Q. Dai, D. Massilani, X. Shen, J. Wang, X. Feng, P. Cao, M.A. Yang, J. Yao, J. Yang, D.B. Madsen, Y. Han, W. Ping, F. Liu, C. Perreault, X. Chen, M. Meyer, J. Kelso, S. Pääbo, Q. Fu, Denisovan DNA in late Pleistocene sediments from Baishiya karst cave on the Tibetan Plateau. Science 370 (6516), 584-587 (2020). 
150. D. Reich, N. Patterson, M. Kircher, F. Delfin, M.R. Nandineni, I. Pugach, A.M-S. Ko, Y-C. Ko, T.A. Jinam, M.E. Phipps, N. Saitou, A. Wollstein, M. Kayser, S. Pääbo, M. Stoneking, Denisova admixture and the first modern human dispersals into Southeast Asia and Oceania. Am. J. Hum. Genet. 89, 516-528 (2011).

151. P. Skoglund, M. Jakobsson. Archaic human ancestry in East Asia. Proc. Natl. Acad. Sci. USA 108, 18301-18306 (2011).

152. M. Mondal, F. Casals, T. Xu, G.M. Dall'Olio, M. Pybus, M.G. Netea, D. Comas, H. Laayouni, Q. Li, P.P. Majumder, J. Bertranpetit, Genomic analysis of Andamanese provides insights into ancient human migration into Asia and adaptation. Nat. Genet. 48, 1066-1070 (2016).

153. S. Sankararaman, S. Mallick, N. Patterson, D. Reich. The combined landscape of Denisovan and Neanderthal ancestry in present day humans. Curr. Biol. 26, 1241-1247 (2016).

154. B. Vernot, S. Tucci, J. Kelso, J.G. Schraiber, A.B. Wolf, R.M. Gittelman, M. Dannemann, S. Grote, R.C. McCoy, H. Norton, L.B. Scheinfeldt, D.A. Merriwether, G.Koki, J.S. Friedlaender, J. Wakefield, S. Pääbo, J.M. Akey, Excavating Neandertal and Denisovan DNA from the genomes of Melanesian individuals. Science 352, 235-239 (2016).

155. M. Larena, J. McKenna, F. Sanchez-Quinto, C. Bernhardsson, C. Ebeo, R. Reyes, O. Casel, J-Y. Huang, K. Pullupul Hagada, D. Guilay, J. Reyes, F. Pir Allian, V. Mori, L.S. Azarcon, A. Manera, C. Terando, L. Jamero Jr., G. Sireg, R. ManginsayTremedal, M.S. Labos, R. Dian Vilar, A. Latiph, R. L. Saway, E. Marte, P. Magbanua, A. Morales, I. Java, R. Reveche, B. Barrios, E. Burton, J.C. Salon, M.J.T. Kels, A. Albano, R.B. Cruz-Angeles, E. Molanida, L. Granehäll, M. Vicente, H. Edlund, J-H. Loo, J. Trejaut, S.Y.W. Ho, L. Reid, K. Lambeck, H. Malmström, C. Schlebusch, P. Endicott, M. Jakobsson, Philippine Ayta possess the highest level of Denisovan ancestry in the world, Current Biology 31(19), 4219-4230.e10 (2021).

156. M. Larena, F. Sanchez-Quinto, P. Sjödin, J. McKenna, C. Ebeo, R. Reyes, O. Casel, J-Y. Huang, K.P. Hagada, D. Guilay, J. Reyes, F. Pir Allian, V. Mori, L.S. Azarcon, A. Manera, C. Terando, L. Jamero Jr, G. Sireg, R. Manginsay-Tremedal, M.S. Labos, R.D. Vilar, A. Latiph, R.L. Saway, E. Marte, P. Magbanua, A. Morales, I. Java, R. Reveche, B. Barrios, E. Burton, J.C. Salon, M.J.T. Kels, A. Albano, R.B. Cruz-Angeles, E. Molanida, L. Granehäll, M. Vicente, H. Edlund, J-H. Loo, J. Trejaut, S.Y.W. Ho, L. Reid, H. Malmström, C. Schlebusch, K. Lambeck, P. Endicott, M. Jakobsson, Multiple migrations to the Philippines during the last 50,000 years. Proc. Natl. Acad. Sci. USA 118, e2026132118 (2021).

157. E.I. Zavala, Z. Jacobs, B. Vernot, M.V. Shunkov, M.B. Kozlikin, A.P. Derevianko, E. Essel, C. de Fillipo, S. Nagel, J. Richter, F. Romagné, A. Schmidt, B. Li, K. O’Gorman, V. Slon, J. Kelso, S. Pääbo, R.G. Roberts, M. Meyer, Pleistocene sediment DNA reveals hominin and faunal turnovers at Denisova cave. Nature 595, 399-403 (2021).

158. Bergström, A., Stringer, C., Hajdinjak, M., E.M.L. Scerri, P. Skoglund. Origins of modern human ancestry. Nature 590, 229237 (2021).

159. M.D. Bosch, M.A. Mannino, A.L. Prendergast, T.C. O’Connell, B. Demarchi, S.M. Taylor, L. Niven, J. van der Plicht, J-J. Hublin, New chronology for Ksâr 'Akil (Lebanon) supports Levantine route of modern human dispersal into Europe. Proc. Natl. Acad. Sci. USA 112 (25), 7683-7688 (2015).

160. Anghelinu M., L. Nita, V. Sitlivy, T. Uthmeier, I. Baltean. Looking around Peştera Cu Oase: The beginnings of Upper Paleolithic in Romania. Quat. Intern. 274, 136-157 (2012).

161. M. Hajdinjak, F. Mafessoni, L. Skov, B. Vernot, A. Hübner, Q. Fu, E. Essel, S. Nagel, B. Nickel, J. Richter, O.T. Moldovan, S. Constantin, E. Endarova, N. Zahariev, R. Spasov, F. Welker, G.M. Smith, V. Sinet-Mathiot, L. Paskulin, H. Fewlass, S. Talamo, Z. Rezek, S. Sirakova, N. Sirakov, S.P. McPherron, T. Tsanova, J-J. Hublin, B.M. Peter, M. Meyer, P. Skoglund, J. Kelso, S. Pääbo, Initial Upper Palaeolithic humans in Europe had recent Neanderthal ancestry. Nature 592, 253-257 (2021).

162. A. Seguin-Orlando, T. S. Korneliussen, M. Sikona, A. S. Malaspinas, A. Manica, I. Moltke, A. Albrechtsen, A. K. Oashot, A. Ko, A. margaryan, V. Mosayev, T. Goebel, M. Westway, D. Lambert, V. Khartanovic, J. D. Wall, P. R. Nigst, R. A. Foley, M. Mirazon Lahr, R. Nielsen, L. Orlando, E. Willerlev, Genomic structure in Europeans dating back at least 36,200 year. Science 346 (6213), 1113-1118 (2014).

163. R. Dinnis, A.A. Bessudnov, T. Devièse, A. Pate, M.V. Sablin, A.A. Sinitsyn, T. Higham, New data for the Early Upper Paleolithic of Kostenki (Russia). J. Hum. Evol. 27, 21e40 (2019).

164. K. Prüfer, C. Posth, H. Yu, A. Stoessel, M.A. Spyrou, T. Deviese, M. Mattonai, E. Ribechini, T. Higham, P. Velemínský, J. Brůžek, J. Krause, A genome sequence from a modern human skull over 45,000 years old from Zlatý kůn̆ in Czechia. Nat Ecol Evol 5, 820-825 (2021).

165. Q. Fu, C. Posth, M. Hajdinjak, M. Petr, S. Mallick, D. Fernanades, A. Furtwängler, W. Haak, M. Meyer, A. Mittnik, B. Nickel, A. Peltzee, N. Rohland, V. Slon, S. Talamo, I. Lazaridis, M. Lipson, I. Mathieson, S. Schiffels, P. Skoglund, A. P. Derevianko, N. Drozdov, V. Slavinsky, A. Tsybankov, R. Grifoni Cremonesi, F. Mallegni, B. Gély, E. Vacca, M. R. González Morales, L. G. Straus, C. Neugebauer-Maresch, M. Teschler-Nicola, S. Constantin, O. T. Moldovan, S. Benazzi, M. Peresani, D. Coppola, M. Lari, S. Ricci, A. Ronchitelli, F. Valentin, C. Thevenet, K. Wehrberger, D. Grigorescu, H. Rougier, I. Crevecoeur, D. Flas, P. Semal, M. A. Mannino, C. Cupillard, H. Bocherens, N. J. Conard, K. Harvati, V. Moiseyev, D. G. Drucker, J. Svoboda, M. P. Richards, D. Caramelli, R. Pinhasi, J. Kelso, N. Patterson, J. Krause, S. Pääbo, D. Reich, The genetic history of Ice Age Europe. Nature 534, 200-205 (2016).

166. I. Mathieson, S. Alpaslan-Roodenberg, C. Posth, A. Szécsényi-Nagy, N. Rohland, S. Mallick, I. Olalde, N. Broomandkhoshbacht, F. Candilio, O. Cheronet, D. Fernandes, M. Ferry, B. Gamarra, G. González Fortez, W. Haak, E. Harney, E. Jones, D. Keating, B. Krause-Kyora, I. Kucukkalipci, M. Michel, A. Mittnik, K. Nägele, Mario Novak, J. Oppenheimer, N. Patterson, S. Pfrengle, K. Sirak, K. Stewardson, S. Vai, S. Alexandrov, K. W. Alt, R. Andreescu, D. Antonovic', A. Ash, N. Atanassova, K. Bacvarov, M. Balázs Gusztáv, H. Bocherens, M. Bolus, A. Boroneant, Y. Boyadzhiev, A. Budnik, J. Burmaz, S. Chohadzhiey, N. J. Conard, R. Cottiaux, M. C`uka, C. Cupillard, D. G. Drucker, N. Elenski, M. Francken, B. Galabova, G. Ganetsovski, B. Gély, T. Hajdu, V. Handzhyiska, K. Harvati, T. Higham, S. Iliev, I. Jankovic', I. Karavanic', D. J. Kennett, D. Komšo, A. Kozak, D. Labuda, M. Lari, C. Lazar, M. Leppek, K. Leshtakov, D. Lo Vetro, D. 
Los, I. Lozanov, M. Malina, F. Martini, K. McSweeney, H. Meller, M. Mend'ušic', P. Mirea, V. Moiseyev, V. Petrova, T. D. Price, A. Simalcsik, L. Sineo, M. Šlaus, V. Slavchev, P. Stanev, A. Starovic', T. Szeniczey, S. Talamo, M. Teschler-Nicola, C. Thevenet, I. Valchev, F. Valentin, S. Vasilyev, F. Veljanovska, S. Venelinova, E. Veselovskaya, B. Viola, C. Virag, J. Zaninovic, S. Zäuner, P. W. Stockhammer, G. Catalano, R. Krauß, D. Caramelli, G. Zarina, B. Gaydarska, M. Lillie, A. G. Nikitin, I. Potekhina, A. Papathanasiou, D. Boric', C. Bonsall, J. Krause, R. Pinhasi, D. Reich, The genomic history of southeastern Europe. Nature 555, 197-203 (2018).

167. W. Haak, I. Lazaridis, N. Patterson, N. Rohland, S. Mallick, B. Llamas, G. Brandt, S. Nordenfelt, E. Harney, K. Stewardson, Q. Fu, A. Mittnik, E. Bánffy, C. Economou, M. Francken, S. Friederich, R.G. Pena, F. Hallgren, V. Khartanovich, A. Khokhlov, M. Kunst, P. Kuznetsov, H. Meller, O. Mochalov, V. Moiseyev, N. Nicklisch, S.L. Pichler, R. Risch, M.A. Rojo Guerra, C. Roth, A. Szécsényi-Nagy, J. Wahl, M. Meyer, J. Krause, D. Brown, D. Anthony, A. Cooper, K.W. Alt, D. Reich, Massive migration from the steppe was a source for Indo-European languages in Europe. Nature 522, 207-211 (2015).

168. F. Sanchez-Quinto, C. Lalueza-Fox, Almost 20 years of Neanderthal palaeogenetics: adaptation, admixture, diversity, demography and extinction. Phil. Trans. R. Soc. B 370, 20130374-20130374 (2015).

169. Z. Jacobs, Bo Li, M.V. Shunkov, M. B. Kozlikin, N. S. Bolikhovskaya, A. K. Agadjanian, V.A. Unliyanov, S.K. Vasiliev, K. O’Gorman, A. P. Derevianko, R.G. Roberts, Timing of archaic hominin occupation of Denisova Cave in southern Siberia. Nature 565, 594-599 (2019).

170. S. Brown, S. Brown, T. Higham, V. Slon, S. Pääbo, M. Meyer, K. Douka, F. Brock, D. Comeskey, N. Procopio, M. V. Schunkov, A. P. Derevianko, M. Buckley, Identification of a new hominin bone from Denisova Cave, Siberia using collagen fingerprinting and mitochondrial DNA analysis. Sci. Rep. 6, 23559 (2016).

171. K. Douka, V. Slon, Z. Jacobs, C. Bronk Ramsey, M.V. Shunkov, A.P. Derevianko, F. Mafessoni, M.B. Kozlikin, Bo Li , R. Grun, D. Comeskey, T. Deviese, S. Brown, B. Viola, L. Kinslev, M. Buckley, M. Meyer, R.G. Roberts, S. Pääbo, J. Kelso, T. Higham, Age estimates for hominin fossils and the onset of the Upper Palaeolithic at Denisova Cave. Nature 565, 640-644 (2019).

172. B. Viola, S. V. Markin, A.P. Buzhilova, M.B. Mednikova, A.L. Cabec, M.V. Shunkov, New Neanderthal remains from Chagyrskaya Cave (Altai mountains, Russian Federation) Am. J. Phys. Anthropol. 147 (54), 293-294 (2012).

173. A.P. Derevianko, M.V. Shunkov, The Sibiyachikha Facies of the Middle Paleolithic of the Altai. Arch. Ethnol. Anthr. Eurasia 41 (1), 89-103 (2013).

174. S.K. Vasiliev, Large mammal fauna from the Pleistocene deposits of Chagyrskaya Cave northwestern Altai (based on 20072011 excavations). Archaeology, Ethnology and Anthropology of Eurasia 41(1), 28-44 (2013).

175. N. Rudaya, S. Vasiliev, B. Viola., S. Talamo, S. Markin, Palaeoenvironments during the period of the Neanderthals settlement in Chagyrskaya cave (Altai Mountains, Russia). Quant. Intl. 467 (Part A), 265-276 (2017).

176. M. Glantz, A. van Arsdale, S. Temirbekov, T. Beeton, How to survive the glacial apocalypse: Hominin mobility strategies in late Pleistocene Central Asia. Quant. Intl. 466 (Part A), 82-92 (2018).

177. I.V. Ovchinnikov, A. Götherström, G.P. Romanova, V.M. Kharitonov, K. Lidén, W. Goodwin, Molecular analysis of Neanderthal DNA from the northern Caucasus. Nature 404, 490-493 (2000).

178. L.V. Golovanova, V.B. Doronichev, N.E. Cleghorn, M.A. Koulkova, T.V. Sapelko, M.S. Shackley, Significance of Ecological Factors in the Middle to Upper Paleolithic Transition. Current Anthropology 51(5), 655-691 (2010).

179. T. Devièse, I. Karavanić, D. Comeskey, C. Kubiak, P. Korlević, M. Hajdinjak, S. Radović, N. Procopio, M. Buckley, S. Paabo, T. Higham, Direct dating of Neanderthal remains from the site of Vindija Cave and implications for the Middle to Upper Paleolithic transition. Proc. Natl. Ac. Sci. US A 114(40), 10606-10611 (2017).

180. W.M. Karriger, C.W. Schmidt, F.H. Smith, Dental Microwear Texture Analysis of Croatian Neandertal Molars. Paleo Anthropology, 172-184 (2016).

181. M.P. Richards, P.B. Pettitt, E. Trinkaus, F.H. Smith, M. Paunović, I. Karavanić, Neanderthal diet at Vindija and Neanderthal predation: the evidence from stable isotopes. Proc. Natl. Acad. Sci. U S A 97(13), 7663-7666 (2000).

182. P. Semal, H. Rougier, I. Crevecoeur, C. Jungels, D. Flas, A. Hauzeur, B. Maureille, M. Germonpré, H. Bocherens, S. Pirson, L. Cammaert, N. de Clerck, A. Hambucken, T. Higham, M. Toussaint, J. van der Plicht, New data on the late Neandertals: Direct dating of the Belgian Spy fossils. Am. J. Phys. Anthr. 138, 421-428 (2009).

183. H. Rougier, P. Semal, (Eds), Spy Cave. 125 years of multidisciplinary research at the Betche aux Rotches (Jemeppe-surSambre, Province of Namur, Belgium). Anthropologica et Praehistorica 1(123), 380 (2013).

184. T. Devièse, G. Abrams, M. Hajdinjak, S. Pirson, I. De Groote, K. Di Modica, M. Toussaint, V. Fischer, D. Comeskey, L. Spindler, M. Meyer, P. Semal, T. Higham, Reevaluating the timing of Neanderthal disappearance in Northwest Europe. Proceedings of the National Academy of Sciences 118(12), e2022466118 (2021).

185. S. El Zaatari, F.E. Grine, P.S. Ungar, J.J. Hublin, Ecogeographic variation in Neandertal dietary habits: evidence from occlusal microwear texture analysis. J. Hum. Evol. 61, 411-424 (2011).

186. F. L'Engle-Williams, C.W. Schmidt, J.L. Droke, J.C. Willman, P. Semal, G. Becam, M-A. de Lumley, Dietary reconstruction of Spy I using dental microwear texture analysis. C. R. Palevol 18, 1083-1094 (2019).

187. K. Hardy, S. Buckley, M.J. Collins, A. Estalrrich, D. Brothwell, L. Copeland, A. García-Tabernero, S. García-Varga, M. de la Rasilla, C. Lalueza-Fox, R. Huguet, M. Bastir, D. Santamaría, M. Madella, J. Wilson, A.F. Cortes, A. Rosas, Neanderthal medics? Evidence for food, cooking, and medicinal plants entrapped in dental calculus. Naturwissenschaften 99(8), 1-10 (2012).

188. A. Radini, E. Nikita, L. Copeland, K. Hardy, Beyond food: The multiple pathways for inclusion of materials into ancient dental calculus. Am. J. Phys. Anthropol. 162, 71-83 (2017).

189. K. Hardy, Plant use in the Lower and Middle Palaeolithic: Food, medicine and raw materials. Quat. Sci. Rev. 191, 393-405 (2018). 
190. H. Rougier, I. Crevecoeur, C. Beauval, C. Posth, D. Flas, C. Wißing, A. Furtwängler, M. Germonpré, A. Gomez-Olivencia, J. van der Plicht, H. Bocherens, J. Krause, Neandertal cannibalism and Neandertal bones used as tools in Northern Europe. Sci. Rep. 6, 29005 (2016).

191. C. Wißing, H. Rougier, I. Crevecoeur, M. Germonpré, Y. I. Naito, P. Semal, H. Bocherens, Isotopic evidence for dietary ecology of late Neandertals in North-Western Europe. Quat. Intl. 411 (Part A), 327-345 (2016).

192. M. Hervella, E. M. Svensson, A. Alberdi, T. Günther, N. Izagirre, A. R. Munters, S. Alonso, M. Ioana, F. Ridiche, A. Socaru, M. Jakobsson, M.G. Netea, C. de-la-Rua, The mitogenome of a 35,000-year- old Homo sapiens from Europe supports a Palaeolithic back-migration to Africa. Sci. Rep. 6, 25501 (2016).

193. Q. Fu, M. Hajdinjak, O.T. Moldovan, S. Constantin, S. Mallick, P. Skoglund, N. Patterson, N. Rohland, I. Lazaridis, B. Nickel, B. Viola, K. Prüfer, M. Meyer, J. Kelso, D. Reich, S. Pääbo, An early modern human from Romania with a recent Neanderthal ancestor. Nature 524(7564), 216-219 (2015).

194. P. Moorjani, S. Sankararaman, Q. Fu., M. Przeworski, N. Patterson, D. Reich, A genetic method for dating ancient genomes provides a direct estimate of human generation interval in the last 45,000 years. Proc. Natl. Acad. Sci. U S A 113(20), 56525657 (2016).

195. E.H.M. Wong, A. Khrunin, Nichols L., D. Pushkarev, Khokhrin D., Verbenko D., O. Evgrafov, J. Knowles, J. Novembre, S. Limborska, A. Valouev, Reconstructing genetic history of Siberian and Northeastern European populations. Genome Research 27, 1-14 (2017).

196. Z.A. Abramova, L'art paléolithique d'Europe orientale et de Sibérie (Jérôme Million, Grenoble, France, 1995).

197. M. Sikora, V. V. Pitulko, V. C. Sousa, M. E. Allentoft, L. Vinner, S. Rasmussen, A. Margaryan, P. de Barros Damgaard, C. de la Fuente, G. Renaud, M. A. Yang, Q. Fu, I. Dupanloup, K. Giampoudakis, C. Nogués-Bravo, C. Rahbek, G. Kroonen, M. Peyrot, M. Gerasimova, E.Y. Pavlova, V. G. Chasnyk, P. S. Grebenyuk, A.V. Gromov, V. I. Khartanovich, V. Moiseyev, A. Yu. Fedorchenko, A.I. Lebedintsev, S. B. Slobodin, B.A. Malyarchuk, R. Martiniano, M. Meldgaard, L. Arppe, J. U. Palo, T. Sundell, K. Mannermaa, M. Putkonen, V. Alexandersen, C. Primeau, N. Baimukhanov, R. S. Malhi, K.-G. Sjögren, K. Kristiansen, A. Wessman, A. Sajantila, M. Mirazon Lahr, R. Durbin, R. Nielsen, D. L. Meltzer, L. Excoffier, E. Willerslev, The population history of northeastern Siberia since the Pleistocene. Nature 579, 172-188 (2019).

198. P. Flegontov, P. Changmai, A. Zidkova A., M.D. Logacheva, N. E. Altinişik, O. Flegontova, M.S. Gelfand, E.S. Gerasimov, E. E. Khrameeva, O. P. Konovalova, T. Neretina, Y.V. Nikolsky, G. Starostin, V. V. Stapanova, I. V. Travinsky, M. Tř́íska. P. Tríska, T.V. Tatarinova, Genomic study of the Ket: a Paleo- Eskimo-related ethnic group with significant ancient North Eurasian ancestry. Sci. Rep. 6, 20768 (2016).

199. M. Heuertz, Documents préhistoriques du territoire luxembourgeois. Le milieu naturel. L'homme et son œuvre. Publications du Musée d'Histoire Naturelle et de La Société des Naturalistes luxembourgeois. Luxembourg, 1, 295 (1969).

200. H. Stäuble, Häuser und absolute Datierung den ältesten Bandkeramik, Universitätsforsch. Prähist. Arch. 117, Bonn, Habelt (2005).

201. T.D. Price, J. Wahl, C. Knipper, E. Burger-Heinrich, G. Kurz, R.A. Bentley, Das bandkeramische Gräberfeld vom 'Viesenhäuser Hof' bei Stuttgart-Mühlhausen: Neue Untersuchungsergebnisse zum Migrationsverhalten im frühen Neolithikum. Fundberichte aus Baden-Württemberg 27, 23-58 (2003). 
bioRxiv preprint doi: https://doi.org/10.1101/2021.10.30.466563; this version posted November 2, 2021. The copyright holder for this preprint (which was not certified by peer review) is the author/funder, who has granted bioRxiv a license to display the preprint in perpetuity. It is made available under aCC-BY-NC-ND 4.0 International license.

\section{Supplementary Tables}




\begin{tabular}{|c|c|c|c|c|c|}
\hline Genome & Identifier & Depository site & $\begin{array}{l}\text { Covera } \\
\text { ge }\end{array}$ & $\begin{array}{c}\text { Conta } \\
\text { minatio } \\
n\end{array}$ & Reference \\
\hline Den D11 & $\begin{array}{l}\text { ENA } \\
\text { PRJEB24663 }\end{array}$ & https://www.ebi.ac.uk/ena/browser/home & 5.63 & & Slon et al. 2018 \\
\hline Den D3 & & http://cdna.eva.mpg.de/denisova/ & 31.59 & & Meyer et al. 2012 \\
\hline Altai Neandertal D5 & ENA PRJEB1265 & https://www.ebi.ac.uk/ena/browser/home & 54.01 & $1 \%$ & Prüfer et al. 2014 \\
\hline Chagyrskaya 8 & & $\begin{array}{l}\text { http://ftp.eva.mpg.de/neandertal/Chagyrskaya } \\
\text { /VCF/ }\end{array}$ & 28.36 & $0.7 \%$ & Mafessoni et al. 2020 \\
\hline Mezmaiskaya 1 & ENA PRJEB1757 & $\begin{array}{l}\text { http://cdna.eva.mpg.de/neandertal/Mezmaisk } \\
\text { aya1/Pruefer etal } 2017 \text { bam/ }\end{array}$ & 2.04 & $<1 \%$ & Prüfer et al. 2017 \\
\hline Spy 94a & $\begin{array}{l}\text { ENA } \\
\text { PRJEB21883 }\end{array}$ & https://www.ebi.ac.uk/ena/browser/home & 1.08 & $1.75 \%$ & Hajdinjak et al. 2018 \\
\hline Vindija 33.19 & $\begin{array}{l}\text { ENA } \\
\text { PRJEB21882 }\end{array}$ & https://www.ebi.ac.uk/ena/browser/home & 31.32 & $<1 \%$ & Prüfer et al. 2017 \\
\hline Mezmaiskaya 2 & $\begin{array}{l}\text { ENA } \\
\text { PRJEB21881 }\end{array}$ & https://www.ebi.ac.uk/ena/browser/home & 1.85 & $0.83 \%$ & Hajdinjak et al. 2018 \\
\hline Les Cottés Z4-1514 & $\begin{array}{l}\text { ENA } \\
\text { PRJEB21875 }\end{array}$ & https://www.ebi.ac.uk/ena/browser/home & 2.94 & $0.18 \%$ & Hajdinjak et al. 2018 \\
\hline Goyet Q56.1 & $\begin{array}{l}\text { ENA } \\
\text { PRJEB21870 }\end{array}$ & https://www.ebi.ac.uk/ena/browser/home & 2.30 & $0.89 \%$ & Hajdinjak et al. 2018 \\
\hline Ust'-Ishim & ENA PRJEB6622 & https://www.ebi.ac.uk/ena/browser/home & 42.72 & $<0.13 \%$ & Fu et al. 2014 \\
\hline Peştera Muierii 1 & $\begin{array}{l}\text { ENA } \\
\text { PRJEB33172 }\end{array}$ & https://www.ebi.ac.uk/ena/browser/home & 17.00 & $1.5 \%$ & Svensson et al. 2021 \\
\hline Mal'ta & $\begin{array}{l}\text { NCBI SRA } \\
\text { SRP029640 }\end{array}$ & $\begin{array}{l}\text { https://www.ncbi.nlm.nih.gov/sra/SRX346836[ } \\
\text { accn] }\end{array}$ & 1.21 & $1.6-2 \%$ & Raghavan et al. 2014 \\
\hline $\begin{array}{l}\text { Loschbour, Motala } \\
12 \text {, Stuttgart }\end{array}$ & ENA PRJEB6272 & https://www.ebi.ac.uk/ena/browser/home & $\begin{array}{l}22.13,2.46 \\
19.28\end{array}$ & $\begin{array}{c}0.4 \% \\
\text { (Loschburg, } \\
\text { Stuttgart) } \\
0.35 \% \\
\text { (Motala 12) } \\
\end{array}$ & Lazaridis et al. 2014 \\
\hline Human reference & GRCH37/hg19 & $\begin{array}{l}\text { http://grch37.ensembl.org/info/data/index.ht } \\
\text { ml }\end{array}$ & & & \\
\hline
\end{tabular}

Table S1. Downloading information for the 16 ancient human genomes and the reference genome considered in this article. From top to bottom, genomes are listed according to dating from the oldest to the most recent within each population: Denisovan (grey), Neandertal (orange), Homo sapiens (purple). 
bioRxiv preprint doi: https://doi.org/10.1101/2021.10.30.466563; this version posted November 2, 2021. The copyright holder for this preprint (which was not certified by peer review) is the author/funder, who has granted bioRxiv a license to display the preprint in perpetuity. It is made available under aCC-BY-NC-ND 4.0 International license.

\begin{tabular}{|c|c|c|c|c|c|}
\hline Fossil remains & $\begin{array}{l}\text { Fossil details } \\
\text { anatomy } \\
\text { sex }\end{array}$ & Geographical location & Cave and layer & $\begin{array}{l}\text { Time period (ybp - } \\
\text { calibrated age) }\end{array}$ & $\begin{array}{l}\text { Relevant publications for the } \\
\text { genome published }\end{array}$ \\
\hline Denisova D11 & $\begin{array}{l}\text { Small bone fragment } \\
\text { Female Den/Hn }\end{array}$ & $\begin{array}{l}\text { Central Asia: Central } \\
\text { Siberia, Altai Moutain }\end{array}$ & $\begin{array}{l}\text { Denisova Cave } \\
\text { Layer 11, East } \\
\text { chamber }\end{array}$ & $118100-79300$ & $\begin{array}{l}\text { Slon et al. Nature } 2018 \\
\text { Douka et al. Nature } 2019\end{array}$ \\
\hline Denisova D3 & $\begin{array}{l}\text { Distal phalanx of the } \\
\text { fifth finger. } \\
\text { Female }\end{array}$ & $\begin{array}{l}\text { Central Asia: Central } \\
\text { Siberia, Altai Moutain }\end{array}$ & $\begin{array}{l}\text { Denisova Cave } \\
\text { Layer 11.2, East } \\
\text { Gallery }\end{array}$ & $76200-51600$ & $\begin{array}{l}\text { Meyer et al. Science } 2012 \\
\text { Reich et al. Nature } 2010 \\
\text { Douka et al. Nature } 2019\end{array}$ \\
\hline Altai Neandertal D5 & $\begin{array}{l}\text { Phalanx foot toe } \\
\text { Female }\end{array}$ & $\begin{array}{l}\text { Central Asia: Central } \\
\text { Siberia, Altai Moutain }\end{array}$ & $\begin{array}{l}\text { Denisova Cave } \\
\text { Layer } 11.4\end{array}$ & 120000 & Prüfer et al. Nature 2014 \\
\hline Chagyrskaya 8 & $\begin{array}{l}\text { Distal manual } \\
\text { phalanx } \\
\text { Female }\end{array}$ & \begin{tabular}{|l|} 
Central Asia: Central \\
Siberia, Charysh River, \\
foothills of the Altai \\
Moutain.
\end{tabular} & Chagyrskaya Cave & $80000-60000$ & Mafessoni et al. PNAS 2020 \\
\hline Mezmaiskaya 1 & $\begin{array}{l}\text { Almost complete } \\
\text { skeleton } \\
\text { Still breast-feeding } \\
\text { Neonate }\end{array}$ & $\begin{array}{l}\text { Eastern Europe: } \\
\text { Southern Russia, } \\
\text { foothills of the North } \\
\text { Caucasus }\end{array}$ & Mezmaiskaya Cave & $70000-60000$ & Prüfer et al. Science 2017 \\
\hline Spy $94 a$ & $\begin{array}{l}\text { Upper right molar } \\
\text { associated to a } \\
\text { maxillary fragment } \\
\text { Male }\end{array}$ & $\begin{array}{l}\text { Western Europe: } \\
\text { Belgium, Namur } \\
\text { province }\end{array}$ & Cave & $49800-42300$ & $\begin{array}{l}\text { Haidinjak et al. Nature } 2018 \\
\text { Devièse et al. PNAS } 2021\end{array}$ \\
\hline Vindija 33.19 & $\begin{array}{l}\text { Fragments of long } \\
\text { bones } \\
\text { Female }\end{array}$ & $\begin{array}{l}\text { Southern Europe: } \\
\text { Croatia, Dinaric Alps }\end{array}$ & Vindija Cave & $47400-44300$ & Prüfer et al. Science 2017 \\
\hline Mezmaiskaya 2 & $\begin{array}{l}\text { Skull fragment } \\
\text { Male? }\end{array}$ & $\begin{array}{l}\text { Eastern Europe: } \\
\text { Foothills of the North } \\
\text { Caucasus }\end{array}$ & Mezmaiskaya Cave & $44.600-42.960$ & Haidinjak et al. Nature 2018 \\
\hline Les Cottés Z4-1514 & $\begin{array}{l}\text { Tooth } \\
\text { NA }\end{array}$ & $\begin{array}{l}\text { Western Europe: } \\
\text { France, Saint-Pierre- } \\
\text { de-Maillé }\end{array}$ & "Les Cottés" cave & $43200-42500$ & Haidinjak et al. Nature 2018 \\
\hline Goyet Q56-1 & $\begin{array}{l}\text { Right Femur } \\
\text { NA }\end{array}$ & $\begin{array}{l}\text { Western Europe: } \\
\text { Belgium, Namur } \\
\text { province }\end{array}$ & $\begin{array}{l}\text { "third cavern" of } \\
\text { Goyet cave }\end{array}$ & $42800-42100$ & Haidinjak et al. Nature 2018 \\
\hline Ust'-ishim & $\begin{array}{l}\text { Femora } \\
\text { Male }\end{array}$ & $\begin{array}{l}\text { Central Asia: North- } \\
\text { Western Siberia, Omsk } \\
\text { province }\end{array}$ & $\begin{array}{l}\text { Cave on the bank of } \\
\text { the Irtysh River }\end{array}$ & $45930-42900$ & Fu et al. Nature 2014 \\
\hline Peștera Muierii 1 & $\begin{array}{l}\text { Temporal bone } \\
\text { Female }\end{array}$ & \begin{tabular}{|l} 
Eastern Europe: \\
Romania, Carpatian \\
mountains
\end{tabular} & "Women's Cave" & $35257+/-259$ & $\begin{array}{l}\text { Svensson et al. Current Biology } \\
2021\end{array}$ \\
\hline Malt'a 1 & $\begin{array}{l}\text { Skeleton burial } \\
\text { Male }\end{array}$ & $\begin{array}{l}\text { Central Asia: Central - } \\
\text { Eastern Siberia, } \\
\text { Bolshaya Belaya river }\end{array}$ & Open air site & 25600 & $\begin{array}{l}\text { Raghavan et al. Nature } 2014 \\
\text { Fiedel \& Kuzmin, } 2007\end{array}$ \\
\hline Loschbour & $\begin{array}{l}\text { Skeleton } \\
\text { Male }\end{array}$ & $\begin{array}{l}\text { Central Europe: } \\
\text { Luxembourg, } \\
\text { Mullerthal }\end{array}$ & Rock shelter & $8200-7900$ & Lazaridis et al. Nature 2014 \\
\hline Motala 12 & $\begin{array}{l}\text { Maxilla (burial) } \\
\text { Male }\end{array}$ & $\frac{\text { Northern Europe: }}{\text { Sweden, Motala }}$ & $\begin{array}{l}\text { Necropolis - } \\
\text { Kanaljorden }\end{array}$ & $8000-7600$ & Lazaridis et al. Nature 2014 \\
\hline Stuttgart & Tooth (burial) & $\begin{array}{l}\text { Central Europe: South- } \\
\text { Western, Germany }\end{array}$ & $\begin{array}{l}\text { Stuttgart- } \\
\text { Mühlhausen }\end{array}$ & 7000 & Lazaridis et al. Nature 2014 \\
\hline
\end{tabular}

Table S2. Description of the fossils of the $\mathbf{1 6}$ individuals whose genomes are analyzed in this article. From top to bottom, genomes are listed according to dating from the oldest to the most recent within each population: Denisovan (grey), Neandertal (orange), Homo sapiens (purple). 


\begin{tabular}{|c|c|c|c|}
\hline GO term & GO description & Copy gain & Copy loss \\
\hline \multicolumn{4}{|c|}{ small molecule metabolic process } \\
\hline GO:0000038 & $\begin{array}{l}\text { very long-chain fatty } \\
\text { acid metabolic process }\end{array}$ & & nea(ACOT1) \\
\hline GO:0035338 & $\begin{array}{l}\text { long-chain fatty-acyl- } \\
\text { CoA biosynthetic } \\
\text { process }\end{array}$ & & nea(ACOT1) \\
\hline GO:0045721 & $\begin{array}{l}\text { negative regulation of } \\
\text { gluconeogenesis }\end{array}$ & hsa(MST1); nea(MST1) & \\
\hline GO:0010510 & $\begin{array}{l}\text { regulation of acetyl- } \\
\text { CoA biosynthetic } \\
\text { process from pyruvate }\end{array}$ & hsa(PDPR); nea(PDPR) & \\
\hline GO:0001676 & $\begin{array}{l}\text { long-chain fatty acid } \\
\text { metabolic process }\end{array}$ & & nea(ACOT1) \\
\hline GO:0050427 & $\begin{array}{l}\text { 3'-phosphoadenosine } \\
\text { 5'-phosphosulfate } \\
\text { metabolic process }\end{array}$ & hsa(SULT1A4) & $\begin{array}{l}\text { den(SULT1A4); } \\
\text { nea(SULT1A4) }\end{array}$ \\
\hline GO:0006637 & $\begin{array}{l}\text { acyl-CoA metabolic } \\
\text { process }\end{array}$ & & nea(ACOT1) \\
\hline GO:0019369 & $\begin{array}{l}\text { arachidonic acid } \\
\text { metabolic process }\end{array}$ & den(CYP2D6); nea(CYP2D6) & \\
\hline \multicolumn{4}{|c|}{ lipid metabolic process } \\
\hline GO:0016042 & lipid catabolic process & nea(CLPS,CLPSL1) & \\
\hline GO:0000038 & $\begin{array}{l}\text { very long-chain fatty } \\
\text { acid metabolic process }\end{array}$ & & nea(ACOT1) \\
\hline GO:0010510 & $\begin{array}{l}\text { regulation of acetyl- } \\
\text { CoA biosynthetic } \\
\text { process from pyruvate }\end{array}$ & hsa(PDPR); nea(PDPR) & \\
\hline GO:0016098 & $\begin{array}{l}\text { monoterpenoid } \\
\text { metabolic process }\end{array}$ & den(CYP2D6); nea(CYP2D6) & \\
\hline GO:0001676 & $\begin{array}{l}\text { long-chain fatty acid } \\
\text { metabolic process }\end{array}$ & & nea(ACOT1) \\
\hline GO:0001523 & $\begin{array}{l}\text { retinoid metabolic } \\
\text { process }\end{array}$ & nea(CLPS) & \\
\hline GO:0008202 & $\begin{array}{l}\text { steroid metabolic } \\
\text { process }\end{array}$ & $\begin{array}{l}\text { den(CYP2D6); hsa(SULT1A4); } \\
\text { nea(CYP2D6) }\end{array}$ & $\begin{array}{l}\text { den(SULT1A4); } \\
\text { nea(SULT1A4) }\end{array}$ \\
\hline GO:0006629 & lipid metabolic process & nea(CLPS,LPA) & \\
\hline GO:0019369 & $\begin{array}{l}\text { arachidonic acid } \\
\text { metabolic process }\end{array}$ & den(CYP2D6); nea(CYP2D6) & \\
\hline
\end{tabular}




\begin{tabular}{|c|c|c|c|}
\hline \multicolumn{4}{|c|}{ sulfur compound metabolic process } \\
\hline GO:0035338 & $\begin{array}{l}\text { long-chain fatty-acyl- } \\
\text { CoA biosynthetic } \\
\text { process }\end{array}$ & & nea(ACOT1) \\
\hline GO:0010510 & $\begin{array}{l}\text { regulation of acetyl- } \\
\text { CoA biosynthetic } \\
\text { process from pyruvate }\end{array}$ & hsa(PDPR); nea(PDPR) & \\
\hline GO:0050427 & $\begin{array}{l}\text { 3'-phosphoadenosine } \\
\text { 5'-phosphosulfate } \\
\text { metabolic process }\end{array}$ & hsa(SULT1A4) & $\begin{array}{l}\text { den(SULT1A4); } \\
\text { nea(SULT1A4) }\end{array}$ \\
\hline GO:0006637 & $\begin{array}{l}\text { acyl-CoA metabolic } \\
\text { process }\end{array}$ & & nea(ACOT1) \\
\hline GO:0051923 & sulfation & hsa(SULT1A4) & $\begin{array}{l}\text { den(SULT1A4); } \\
\text { nea(SULT1A4) }\end{array}$ \\
\hline \multicolumn{4}{|c|}{ carbohydrate metabolic process } \\
\hline GO:0005975 & $\begin{array}{l}\text { carbohydrate } \\
\text { metabolic process }\end{array}$ & & $\begin{array}{l}\text { den(AMY1B); } \\
\text { nea(AMY1B) }\end{array}$ \\
\hline GO:0045721 & $\begin{array}{l}\text { negative regulation of } \\
\text { gluconeogenesis }\end{array}$ & hsa(MST1); nea(MST1) & \\
\hline \multicolumn{4}{|c|}{ cofactor metabolic process } \\
\hline GO:0035338 & $\begin{array}{l}\text { long-chain fatty-acyl- } \\
\text { CoA biosynthetic } \\
\text { process }\end{array}$ & & nea(ACOT1) \\
\hline GO:0010510 & $\begin{array}{l}\text { regulation of acetyl- } \\
\text { CoA biosynthetic } \\
\text { process from pyruvate }\end{array}$ & hsa(PDPR); nea(PDPR) & \\
\hline GO:0006637 & $\begin{array}{l}\text { acyl-CoA metabolic } \\
\text { process }\end{array}$ & & nea(ACOT1) \\
\hline \multicolumn{4}{|c|}{ biological process } \\
\hline GO:0009812 & $\begin{array}{l}\text { flavonoid metabolic } \\
\text { process }\end{array}$ & hsa(SULT1A4) & $\begin{array}{l}\text { den(SULT1A4); } \\
\text { nea(SULT1A4) }\end{array}$ \\
\hline GO:0006508 & proteolysis & $\begin{array}{l}\text { den(PGA4); hsa(MST1,PGA4); } \\
\text { nea(MST1,PGA4,LPA) }\end{array}$ & \\
\hline GO:0043085 & $\begin{array}{l}\text { positive regulation of } \\
\text { catalytic activity }\end{array}$ & nea(CLPS,CLPSL1) & \\
\hline GO:0090350 & $\begin{array}{l}\text { negative regulation of } \\
\text { cellular organofluorine } \\
\text { metabolic process }\end{array}$ & den(CYP2D6); nea(CYP2D6) & \\
\hline GO:0007586 & digestion & $\begin{array}{l}\text { den(PGA4); } \\
\text { hsa(PGA4,NPY4R); }\end{array}$ & $\begin{array}{l}\text { den(AMY1B); } \\
\text { nea(AMY1B) }\end{array}$ \\
\hline
\end{tabular}




\begin{tabular}{|c|c|c|c|}
\hline & & $\begin{array}{l}\text { nea(CLPS,CLPSL1,PGA4,NPY4 } \\
\text { R) }\end{array}$ & \\
\hline GO:0016311 & dephosphorylation & hsa(PDPR); nea(PDPR) & \\
\hline GO:0006584 & $\begin{array}{l}\text { catecholamine } \\
\text { metabolic process }\end{array}$ & hsa(SULT1A4) & $\begin{array}{l}\text { den(SULT1A4); } \\
\text { nea(SULT1A4) }\end{array}$ \\
\hline GO:0044241 & lipid digestion & nea(CLPS) & \\
\hline GO:0017144 & drug metabolic process & den(CYP2D6); nea(CYP2D6) & \\
\hline GO:0009804 & $\begin{array}{l}\text { coumarin metabolic } \\
\text { process }\end{array}$ & den(CYP2D6); nea(CYP2D6) & \\
\hline GO:0044267 & $\begin{array}{l}\text { cellular protein } \\
\text { metabolic process }\end{array}$ & $\begin{array}{l}\text { den(PGA4); hsa(PGA4); } \\
\text { nea(PGA4) }\end{array}$ & \\
\hline GO:0009820 & $\begin{array}{l}\text { alkaloid metabolic } \\
\text { process }\end{array}$ & den(CYP2D6); nea(CYP2D6) & \\
\hline GO:0051100 & $\begin{array}{l}\text { negative regulation of } \\
\text { binding }\end{array}$ & den(CYP2D6); nea(CYP2D6) & \\
\hline GO:0010951 & $\begin{array}{l}\text { negative regulation of } \\
\text { endopeptidase activity }\end{array}$ & nea(LPA) & \\
\hline GO:0055114 & $\begin{array}{l}\text { oxidation-reduction } \\
\text { process }\end{array}$ & $\begin{array}{l}\text { den(CYP2D6); hsa(PDPR); } \\
\text { nea(PDPR,CYP2D6) }\end{array}$ & \\
\hline GO:0046483 & $\begin{array}{l}\text { heterocycle metabolic } \\
\text { process }\end{array}$ & den(CYP2D6); nea(CYP2D6) & \\
\hline GO:0032094 & response to food & nea(CLPS,CLPSL1) & \\
\hline GO:0006805 & $\begin{array}{l}\text { xenobiotic metabolic } \\
\text { process }\end{array}$ & $\begin{array}{l}\text { den(CYP2D6); hsa(SULT1A4); } \\
\text { nea(CYP2D6) }\end{array}$ & $\begin{array}{l}\text { den(SULT1A4); } \\
\text { nea(SULT1A4) }\end{array}$ \\
\hline GO:0007631 & feeding behavior & hsa(NPY4R); nea(NPY4R) & \\
\hline GO:0070989 & $\begin{array}{l}\text { oxidative } \\
\text { demethylation }\end{array}$ & den(CYP2D6); nea(CYP2D6) & \\
\hline GO:0042157 & $\begin{array}{l}\text { lipoprotein metabolic } \\
\text { process }\end{array}$ & nea(LPA) & \\
\hline \multicolumn{4}{|c|}{ catabolic process } \\
\hline GO:0009822 & $\begin{array}{l}\text { alkaloid catabolic } \\
\text { process }\end{array}$ & den(CYP2D6); nea(CYP2D6) & \\
\hline GO:0042737 & drug catabolic process & den(CYP2D6); nea(CYP2D6) & \\
\hline GO:0016042 & lipid catabolic process & nea(CLPS,CLPSL1) & \\
\hline GO:0030163 & $\begin{array}{l}\text { protein catabolic } \\
\text { process }\end{array}$ & $\begin{array}{l}\text { den(PGA4); hsa(PGA4); } \\
\text { nea(PGA4) }\end{array}$ & \\
\hline
\end{tabular}

Table S3. Gene Ontology terms associated with the 11 genes presenting differential $\mathrm{CNV}$ in archaic populations compared to the reference human genome. The first two columns report the GO term and the GO description for the genes presenting a gain (third column) or loss (fourth column) of copy number in Denisovan (den), Neandertal (nea) and Homo sapiens (hsa) populations compared to the reference human genome. The names of the genes associated to the given GO-term are reported in parenthesis. 


\begin{tabular}{|c|c|c|}
\hline Gene & Main tissues & Other tissues \\
\hline \multirow[t]{2}{*}{ AMY1A/B/C } & Salivary gland & \multirow[t]{2}{*}{ NA } \\
\hline & Pancreas & \\
\hline SULT1A3/4 & $\begin{array}{l}\text { Gastrointestinal tract (small } \\
\text { intestine) }\end{array}$ & Appendix, blood \\
\hline \multirow[t]{2}{*}{ ACOT1 } & Liver \& Gall bladder & \multirow{2}{*}{$\begin{array}{l}\text { Appendix, Gastrointestinal tract, } \\
\text { Salivary gland, and many others }\end{array}$} \\
\hline & Kidney & \\
\hline CLPS & Pancreas & NA \\
\hline \multirow[t]{2}{*}{ CLPSL1 } & Pancreas & \multirow[t]{2}{*}{ NA } \\
\hline & Male tissues & \\
\hline LPA & Liver \& Gall bladder & NA \\
\hline CYP2D6 & Liver \& Gall bladder & Gastrointestinal tract \\
\hline MST1 & Liver \& Gall bladder & $\begin{array}{l}\text { Gastrointestinal tract and many } \\
\text { others }\end{array}$ \\
\hline PDPR & $\begin{array}{l}\text { Gastrointestinal tract and many } \\
\text { other tissues }\end{array}$ & NA \\
\hline PGA3 & Gastrointestinal tract (stomach) & NA \\
\hline NPY4R & Gastrointestinal tract & Skin and many other tissues \\
\hline
\end{tabular}

Table S4. Primary and secondary tissues where the 11 genes are expressed. The 11 genes in Table 1 are expressed in several tissues. We list the tissues where they most (Main tissues) and less (Other tissues) strongly expressed. This information is extracted from the Human Protein Atlas Database (www.proteinatlas.org/) where RNA and protein expression is provided together with extra functional characteristics. 


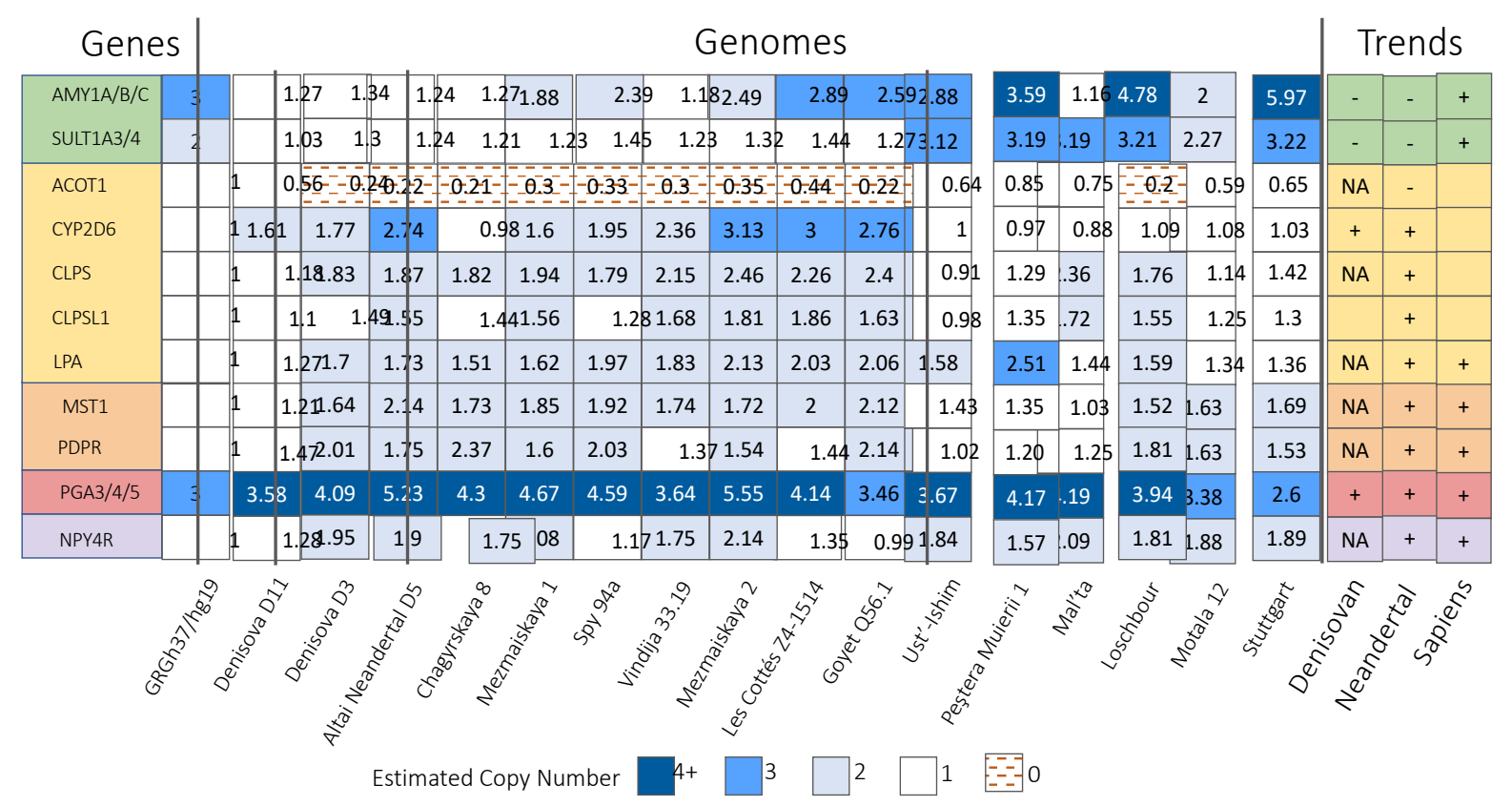

Table S5. Estimated haploid copy number for genes related to digestion in ancient genomes and human population CNV trends (Complement to Table 1). From left to right, the exact estimated gene copy number is reported for all genes and all genomes (see Methods) from Denisovan, Neandertal and Sapiens populations. Genomes within a population are ordered from the oldest to the youngest. Blue shades correspond to the number of gene copies after mapping sequencing reads on the reference genome of modern humans GRGh37/hg19. 